Article

\title{
Chemical Composition of Bulk Precipitation and Its Toxicity Potential Index in the Metropolitan Area of Monterrey, Northeastern Mexico
}

\author{
Darithsa Loya-González ${ }^{1}$, , Daniel López-Serna ${ }^{2}$ (D) Juan Manuel Alfaro-Barbosa ${ }^{2}$, \\ Antonio López-Reyes ${ }^{2}$, Humberto González-Rodríguez ${ }^{1}$ and Israel Cantú-Silva ${ }^{1 \text {,* }}$ \\ 1 Faculty of Forest Science, Autonomous University of Nuevo Leon, National Highway No. 85, Km 145, \\ Linares, Nuevo León 67700, Mexico; darithsa.loyagn@uanl.edu.mx (D.L.-G.); \\ humberto.gonzalezrd@uanl.edu.mx (H.G.-R.) \\ 2 Faculty of Chemical Science, Autonomous University of Nuevo Leon, Av. Universidad S/N, \\ Ciudad Universitaria, San Nicolás de los Garza, Nuevo León 66451, Mexico; \\ daniel.lopezsr@uanl.edu.mx (D.L.-S.); juan.alfarobrb@uanl.edu.mx (J.M.A.-B.); \\ antonio.lopezry@uanl.edu.mx (A.L.-R.) \\ * Correspondence: israel.cantusl@uanl.edu.mx; Tel.: +52-821-2124895 (ext. 121)
}

Received: 17 October 2020; Accepted: 7 December 2020; Published: 8 December 2020

\begin{abstract}
The rainwater chemistry within the Metropolitan Area of Monterrey (MAM) was studied during a one-year period (January 2019-January 2020) in seven sampling sites. The metal concentration of $\mathrm{Zn}, \mathrm{Fe}, \mathrm{Cd}, \mathrm{Cu}, \mathrm{Ni}$, and $\mathrm{Mn}$ was analyzed in bulk samples and the toxicity potential (TP) was calculated for each metal. A canonical correspondence analysis (CCA) was applied to identify the relationship between environmental variables and metals concentrations. An average of $26.6 \pm 10 \mathrm{~mm}$ of rainfall was obtained. A mean $\mathrm{pH}$ of $7.2 \pm 0.3$ and a mean electrical conductivity of $177.8 \pm 8.7 \mu \mathrm{S} \mathrm{cm}{ }^{-1}$ were observed. The average concentration of metals in all sites follows a descending order of $\mathrm{Fe}>\mathrm{Zn}>\mathrm{Mn}>\mathrm{Cu}>\mathrm{Ni}>\mathrm{Cd}$. The university site shows the highest averages of $\mathrm{Fe}, \mathrm{Zn}, \mathrm{Cu}$, and $\mathrm{Mn}$, which is attributed to its proximity to the metallurgical industry. The TP value of $\mathrm{Cd}$ reflects a risk in all sites and Fe only for the Universidad, Obispado, Pastora, and Santa Catarina sites, using as a reference value the Environmental Protection Agency (EPA) Drinking Water Regulations and Mexican norm NOM-127-SSA1-1994. The CCA analysis showed that only Ni and $\mathrm{Cd}$ had a strong correlation with the environmental variable of relative humidity of air.
\end{abstract}

Keywords: rainwater chemistry; toxicity potential; pollution; Metropolitan Area of Monterrey

\section{Introduction}

The chemical composition of rainwater is highly dependent on the concentration of atmospheric pollutants and particulate matter; therefore, it can be used as an indicator of air quality in a given area [1]. The analysis of rainwater provides important information for the atmospheric chemical composition, mechanisms that influence the distribution and transport of atmospheric chemical species and their possible source of origin [2]. In recent decades, a large number of studies have been conducted in this regard, to determine the chemical composition of rainwater in different regions, the local and regional dispersal mechanisms, the contributing emission sources, and the environmental effects of the deposition of substances into the surface [1-5]. Chemical compounds transferred from the atmosphere to the soil surface through rain, called wet deposition, interact with water vapor molecules during cloud formation or can be washed away by rain, thus mobilizing some pollutants to the ground or aquatic surfaces, triggering alterations within forest or urban ecosystems (acid deposition, deposition of trace metals and eutrophication) and in the biogeochemical cycles [6]. Furthermore, the chemical composition 
of rainwater not only depends on the concentrations and the type of substances but also on the collection processes of chemical species by rain and meteorological factors [7]. The type and concentrations of chemical species in rainwater vary between locations and regions. In addition, it reflects the influence of local sources, atmospheric transport conditions, atmospheric temporal development, and its level of contamination [8]. Airmass trajectories combined with chemical composition of precipitation data provide valuable information about the origin of air pollutants. The understanding of patterns of air contamination distribution is necessary to protect the local air quality and ecosystems [9]. In some regions, the local emissions are not significant for the levels of air contamination reported, or in some cases the chemical compounds found in the air do not correspond to local emission sources; this is because the air mass transports pollutants from other regions [10]. In order to improve the policies that regulate the emission of air pollutants and to understand the behavior of the movement of regional or global emissions, some studies in recent decades have focused on the analysis of long-range transport of pollutants, potential sources, and meteorological conditions, combing these parameters to provide a precise modeling of air mass and contaminant trajectories [1,5,11].

At the international level, studies on the flow of major ions $\left(\mathrm{Ca}^{2+}, \mathrm{K}^{+}, \mathrm{Mg}^{2+}, \mathrm{Na}^{+}, \mathrm{NH}_{4}^{+}, \mathrm{Cl}^{-}\right.$, $\mathrm{NO}_{3}{ }^{-}, \mathrm{SO}_{4}{ }^{2-}$, and $\mathrm{HCO}_{3}{ }^{-}$) have been widely reported, showing their abundance, deposition patterns, and principal emission sources, showing the relationship between the acid and alkaline components and their effect on the environment $[12,13]$. In addition, trace metals in rainwater have been widely documented, mainly for metals or metalloids that represent a risk due to their toxicity to health and ecosystems, such as mercury $(\mathrm{Hg})$, lead $(\mathrm{Pb})$, cadmium $(\mathrm{Cd})$, among others $[14,15]$. These potentially toxic metals have increased their presence in the atmosphere due to industrialization and urban growth. On a regional scale, it has been identified that atmospheric deposition is the main source of metal input, especially in agricultural or natural systems [15].

The Metropolitan Area of Monterrey (MAM) located in the Northeast of Mexico, in Nuevo Leon state, contributes with 7.4\% of the national Gross Domestic Product (GDP). It is the third most important industrial city in Mexico and its GDP is acquired through the manufacturing industry located in the North and Northeast area of the MAM (around 24\%) [16]. In addition, the accelerated growth of the region and its industrial activity has identified this area as one of the most populated and polluted cities in Latin America [17], which regularly exhibits problems of air pollution caused by particulate matter and ozone [18]. Few studies regarding the chemistry of rain have been carried out in this city [19-21]. However, these studies have been performed taking into account a single sampling point or a few areas in the city. Moreover, there is no clear correlation between environmental parameters (such as humidity or suspended particulate material) with the concentration of elements and the relationships have not been carried out using precise statistical techniques (such as canonical correlation analysis). There were only some inferences regarding the wind direction and its influence on the movement of the emissions. Furthermore, these studies were carried out several years ago and a complete interpretation of the current situation of the city has not yet been achieved. In addition, none have evaluated the toxicity of metals that can be deposited on the surface.

This research reports a case study conducted in the MAM, northeastern Mexico. The study area was chosen because it is characterized by high industrialization and to the extent of our knowledge, there are no data relating to the metal concentration in bulk precipitation and their toxicity potential. Thus, the aim of this study was (1) to analyze the concentrations and trends of metals $(\mathrm{Zn}, \mathrm{Fe}, \mathrm{Cu}, \mathrm{Ni}$, $\mathrm{Mn}, \mathrm{Cd}, \mathrm{Pb}$, and $\mathrm{Cr}$ ) in the rainfall within different sites along a one-year period, (2) to evaluate if the metals concentrations in rainwater represent a potential for toxicity and (3) to identify the relationship between metal deposition through rainwater and environmental variables. Hence, this study was able to identify environmental patterns that favor the presence of certain elements like cadmium in rainwater and its potential risk for human health and ecosystems. 


\section{Materials and Methods}

\subsection{Study Area}

The sampling sites are located in the MAM $\left(25^{\circ} 40^{\prime} \mathrm{N}, 100^{\circ} 18^{\prime} \mathrm{O}\right.$, Elevation $\left.540 \mathrm{~m}\right)$, which has an area of $7657 \mathrm{~km}^{2}$. The MAM is the most industrialized and populated $(4,106,054$ inhabitants in 2015 [22])urban center in northeast Mexico, with more than two million vehicles, around two hundred industries of various branches (cement, glass, steel, textile, chemical, oil refinery, among others) and medium or small businesses/factories [18]. The climate is semidry and warm, with an average annual precipitation of $623 \mathrm{~mm}$ and a mean annual temperature of $32{ }^{\circ} \mathrm{C}$, which can reach $40^{\circ} \mathrm{C}$ in summer and $-2{ }^{\circ} \mathrm{C}$ in winter. The prevailing winds come from the east and southeast during summer and from the northeast during winter. It is surrounded by the Sierra Madre Oriental Mountain range, the Cerro de la Silla, the Cerro de las Mitras, and the Cerro del Topo Chico, which constitute a natural orographic barrier, which prevents the flow of air to the outside of the MAM and thus allowing for atmospheric pollutants to remain trapped within the urban basin [22]. Due to the orographic conditions of the region, its industrial and population growth, its increase in vehicle fleet, and the lack of an adequate urban development planning, this area shows air pollution problems [22,23]. The MAM is integrated by 13 municipalities that have different land use characteristics: preferably residential-commercial areas located in the south-southeast, areas with a high presence of industries in north-northwest, and commercial areas in central-northwest zone.

Thus, to carry out this study, six of the thirteen municipalities of the MAM were selected (General Escobedo, San Nicolás de los Garza, Monterrey, Guadalupe, Santa Catarina, and Cadereyta Jiménez) to establish a sampling site in each county. However, within the municipality of Monterrey, which is the state capital, two sampling sites were selected, one in the central area and another in the southernmost point of the city. The sampling sites were located at the stations of the environmental monitoring network of the Nuevo Leon state government. Figure 1 shows the municipalities of the MAM and the monitoring sites selected for this study.

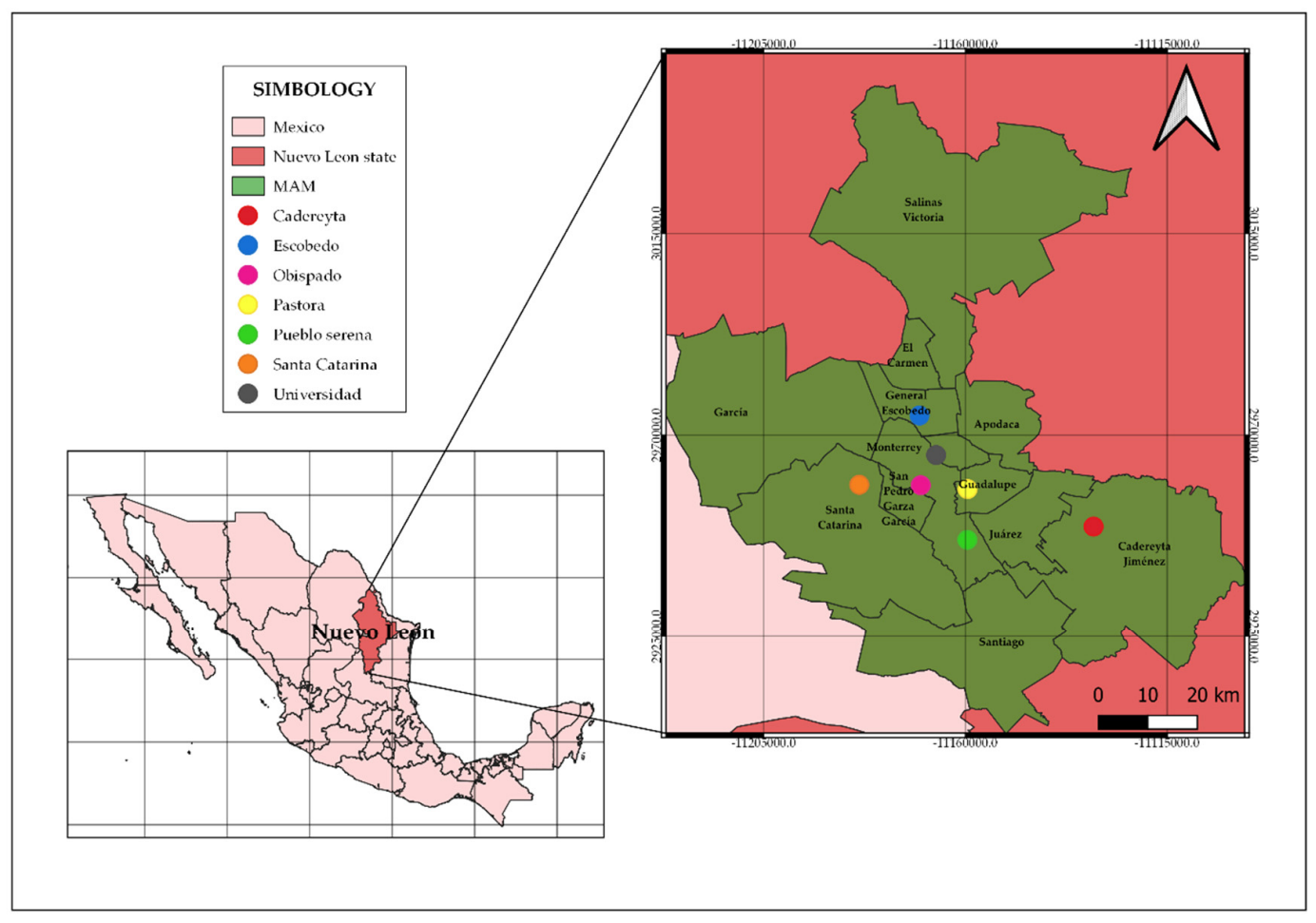

Figure 1. Map of the Metropolitan Area of Monterrey and locations of the monitoring sites (dots in different colors). 
The monitoring sites selected in the present study have different gradients of urbanization or industrialization. Cadereyta site (urban/industrial) highlights the oil refinery and the broom factories. Escobedo site (industrial/high traffic) stands out for its industrial manufacturing activity and its proximity to a high vehicular load avenue (Northeast highway loop). Obispado site (urban/high traffic) corresponds to the downtown area, which is characterized by its commercial activity and many relevant avenues connecting the city. Pueblo Serena (urban/high traffic) is the southern monitoring point, located near National Highway 85, which connects central and southern Mexico to the border city of Nuevo Laredo. Pastora site (urban) is located in the La Pastora Zoo of the MAM near Cerro de la Silla. Santa Catarina site (industrial/high traffic) is characterized by industrial activity (paints, ceramics, plastics, agricultural, aluminum, etc.) and high vehicular traffic since this site connects the MAM with the neighboring state of Coahuila. Finally, Universidad site (urban/industrial), receives its name thanks to the fact that the sampling point is located within the Autonomous University of Nuevo León, which is located near metallurgical industries and avenues that connect the city with the university campus area.

\subsection{Sampling Method}

The rainwater collectors were nonautomatic. The sample collector comprised a 10-L capacity plastic cylinder, in which a funnel of $22.5 \mathrm{~cm}$ of diameter was placed, filling the free space between the funnel and the lid with cold silicone to avoid sample contamination. A plastic mesh was also placed over the funnel to prevent the entry of insects or debris. With the objective of obtaining replications at each selected site, three collectors were placed on the roof of the environmental monitoring station. The collectors remained open during the experimental period, for which it was considered that the quantified deposition was the bulk deposition (wet and dry). The names of the monitoring sites are denoted according to the station location nomenclature given by the state government environmental monitoring system (SIMA). The monitoring period ranged from 30 January 2019 to 30 January 2020. The collection of rainwater samples was carried out on a rainfall event basis. A singular rain event was considered to be that in which the fall of water remained uninterrupted for less than eight hours. When a dry period of more than $8 \mathrm{~h}$ was reached, it was considered a new event. Each sample was collected taking care of not mixing different rainfall events [24].

After each rainfall event, the volume of rainwater was measured. Then, the sample was transferred into sterilized polyethylene bottles with a capacity of $125 \mathrm{~mL}$. The collected samples were immediately placed in a cooler to be transported to the laboratory for further analysis. The sample collectors were thoroughly rinsed with deionized water several times and then placed back at their fixed sampling sites after each sample collection. All those rainfall events in which the rain collectors did not attain a minimum of $125 \mathrm{~mL}$ of sample were discarded, because they did not fulfill the minimum amount required for chemical analyses.

\subsection{Environmental Variables and Particulate Matter Concentrations in the MAM}

Some environmental variables and the concentrations of particulate matter in suspension $\left(\mathrm{PM}_{10}\right.$ and $\mathrm{PM}_{2.5}$ ) were used to describe the conditions of the monitoring sites, which will be referred on the document as the set of environmental variables. The environmental variables were obtained directly from the website of the National Institute of Ecology and Climate Change, through its SINAICA platform for the environmental monitoring stations corresponding to the sampling sites [25]. The wind rose was obtained using the WRPLOT software (WRPLOT, version 8.0.2 @ Lakes Environmental Software, Waterloo, ON, Canada). Then the environmental variables considered for the study (relative humidity, wind direction and speed, and for air quality the concentration of $\mathrm{PM}_{10}$ and $\mathrm{PM}_{2.5}$ ) were correlated to the concentrations found in the rainwater.

To identify the possible origin of the air masses that reached the MAM during the rain events analyzed for the period of January 2019-January 2020, the movement of the air masses' trajectories was tracked, taking as reference two specific rain events (5 March 2019 and 11 July 2019) and a center 
point in the MAM that corresponds to the Obispado site, taking into account $24 \mathrm{~h}$ before the rain event and the prevailing conditions during the rain event. For the air mass trajectory simulations modeling the Hybrid Single-Particle Lagrangian Integrated Path Model (HYSPLIT) was used, based on $1^{\circ} \times 1^{\circ}$ meteorological data (GDAS_Global Data Assimilation System).

\subsection{Chemical Analyses}

The $\mathrm{pH}$ and electrical conductivity (EC) were measured using an Oakton Waterproof $\mathrm{pH} / \mathrm{CON}$ 10 digital meter after each event. Previous to the $\mathrm{pH}$ and $\mathrm{EC}$ determinations, the Oakton meter was calibrated using $\mathrm{pH}$ buffer solutions with values of 4,7 , and 10 . In the case of conductivity, a conductivity standard with a value of $1413 \mu \mathrm{S} \mathrm{cm}^{-1}$ was used. Later $125 \mathrm{~mL}$ of samples were taken (in triplicate) and stored in containers of polyethylene, for their conservation they were acidified with nitric acid $\left(\mathrm{HNO}_{3}\right)$ and refrigerated at $4{ }^{\circ} \mathrm{C}$ prior to chemical analysis. To determine the concentration of the elements in rainwater, the samples were treated by acid digestion using ultra-pure nitric acid $\left(\mathrm{HNO}_{3}\right)$, following the method of the US Environmental Protection Agency (EPA) 3010A, in order to eliminate the presence of organic matter. To proceed with the measurement and to maintain the integrity of the instrument analysis equipment, the samples were filtered through Whatman ${ }^{\circledR}$ no. 42 cellulose membranes to remove particles. For selected elements $(\mathrm{Zn}, \mathrm{Fe}, \mathrm{Cu}, \mathrm{Ni}, \mathrm{Mn}, \mathrm{Pb}, \mathrm{Cd}$, and $\mathrm{Cr}$ ), their concentrations and the corresponding multielement calibration standard curves were constructed. Values from 10 to $400 \mu \mathrm{g} \mathrm{L}^{-1}$ were used for each element. An atomic emission spectroscopy equipment (Agilent MP-AES, model 4200, (C)Agilent Technologies Inc., Sta Clara, CA, USA) was used. The rainwater samples were analyzed in triplicate to ensure precision in the determination of the elements. Additionally, samples that fell outside the working range of the calibration curve were adequately diluted to achieve their reading. For QA/QC, blanks and standards were run in duplicate after every 10 samples.

\subsection{Toxicity Potential Index}

The toxicity potential index (TP) of rainwater and heavy metal chemistry in wet deposition was calculated using the recommended upper limits for metal values to the observed median values in wet deposition as described by Keresztesi et al. (2020), according to the following equation:

$$
\mathrm{TP}=\frac{\text { Concentration of metal in wet deposition }}{\text { Recommended upper limits for metal concentration }}
$$

where a TP value greater than 1 implies a toxic deposition potential. In order to know this value for each monitoring site, the maximum permissible Mexican limit for drinking water (NOM-127-SSA1-1994) was selected as a reference value: for $\mathrm{Cd}\left(0.005 \mathrm{mg} \mathrm{L}^{-1}\right), \mathrm{Cu}\left(2 \mathrm{mg} \mathrm{L}^{-1}\right), \mathrm{Fe}\left(0.30 \mathrm{mg} \mathrm{L}^{-1}\right) \mathrm{Mn}\left(0.15 \mathrm{mg} \mathrm{L}^{-1}\right)$ and $\mathrm{Zn}\left(5 \mathrm{mg} \mathrm{L}^{-1}\right)$ [26], which represents the measured concentration in water (in suspension or diluted) that should not be exceeded for human use and consumption. In addition, the EPA's standard for drinking water was also employed, in order to compare the indexes achieved, taking into account that reference values have different levels of restrictions; for the EPA, MCL (Maximum Concentration Levels) values were used: for $\mathrm{Cd}\left(0.005 \mathrm{mg} \mathrm{L}^{-1}\right)$ and for the rest of the elements $(\mathrm{Zn}, \mathrm{Fe}, \mathrm{Cu}$ and $\mathrm{Mn})$ the values that the EPA considers as Secondary Drinking Water Regulation $\left(5,0.3,1,0.05 \mathrm{mg} \mathrm{L}^{-1}\right.$, respectively). For studied metals at each monitoring site, the average concentration value was used as denoted above.

\subsection{Statistical Analyses}

The concentration of studied metals, $\mathrm{pH}, \mathrm{EC}$, and precipitations values were used to perform the statistical analyses. First, the Kolmogorov-Smirnov test ( $\alpha=95 \%$ ) was carried out to verify the normal distribution assumptions of data. Results showed lack of normality for all investigated variables. Thus, the Kruskal-Wallis test ( $\alpha=95 \%$ ) was performed in order to detect significant differences in the studied 
variables among sampling sites and sampling dates. A descriptive statistical analysis (mean, variance, standard deviation, standard error, minimum, and maximum value) for the concentrations of each metals analyzed at each site, as well as $\mathrm{pH}$ and electrical conductivity, were carried out. The Spearman correlation analysis was performed to determine relationships between all metal concentration values. The SPSS ${ }^{\circledR}$ software (Statistical Package for Social Sciences, version 22 for Windows, SPSS Inc., Chicago, IL, USA) was used to carry out all statistical procedures.

A canonical correlation analysis was applied to determine the relationships between the prevailing environmental variables one day before the rain event and the presence of the metals found in the rainwater. Data was analyzed using the RStudio(C) software (RStudio, version 1.2.5033 for Windows, 2009-2019, RStudio, Inc., Boston, MA, USA). For the correlation graph display between environmental variables and element concentration, the CANOCO Software for Windows version 4.56 was used (Canonical Community Ordination, version 4.5 for Windows, Microcomputer Power. Ithaca, New York, NY, USA).

\section{Results}

\subsection{Environmental Variables}

A total of 12, 15, 18, 21, 19, 17, and 18 rain events were collected for the sites of Cadereyta, Escobedo, Obispado, Pastora, Pueblo Serena, Santa Catarina, and Universidad, respectively. An annual accumulated average precipitation of $448.23 \mathrm{~mm}$ (2019-2020) was registered. The average precipitation between collected events was $26.62 \pm 10.22 \mathrm{~mm}$. A minimum value of $1.26 \mathrm{~mm}$ and a maximum of $252.21 \mathrm{~mm}$ corresponding to the event related to the tropical storm Fernand were noted. The amount of precipitation by rainfall event is shown in Figure 2. The amount of precipitation corresponding to tropical storm Fernand (7 September 2019) was no shown in this figure since it breaks the tendency in rain events. The Kruskal-Wallis test shows no significant differences for rainfall amount between sites, but the differences are significant between one rain event and another.

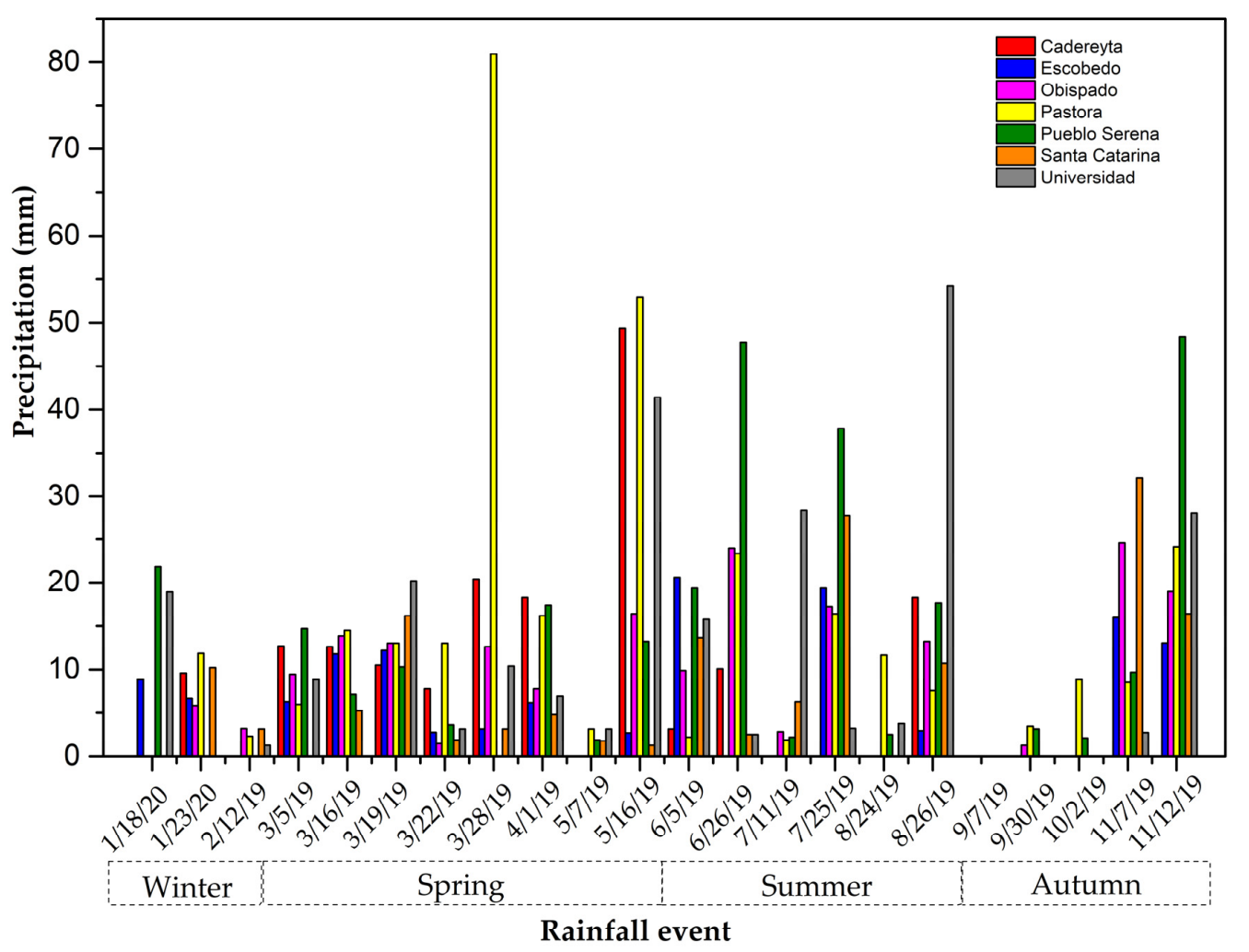

Figure 2. Precipitation amount for each rainfall event in all monitoring sites. 
Average relative humidity for all the sites during the study period was $60.37 \pm 0.28 \%$, with a minimum value of $0 \%$ and a maximum of $97 \%$. The sites Pueblo Serena and Obispado registered the higher and lower mean relative humidity values with figures of $63.50 \%$ and $57.76 \%$, respectively.

The wind speed showed a mean value of $6.53 \pm 0.05 \mathrm{~m} \mathrm{~s}^{-1}$, with a minimum of $0.1 \mathrm{~m} \mathrm{~s}^{-1}$ (calm winds) and a maximum of $100 \mathrm{~m} \mathrm{~s}^{-1}$. The extreme values of strong winds could be related to the presence of the tropical storm Fernand in the month of September 2019. During the experimental period, the site with the highest $\left(12.43 \mathrm{~m} \mathrm{~s}^{-1}\right)$ and lowest $\left(2.48 \mathrm{~m} \mathrm{~s}^{-1}\right)$ wind mean speeds were Pastora and Pueblo Serena, respectively. The dominant annual winds blow from the Northeast, East, and Southeast for most of the monitoring stations.

The wind direction and speed were represented through the wind rose that comprises the entire study period; from January 2019 to January 2020 as shown in Figure 3. It should be noted that tropical storm Fernand caused an alteration in the annual average of rain and wind speed. Given the nature of the storm, the results for the event in which the tropical storm influenced the data were not taken into consideration.

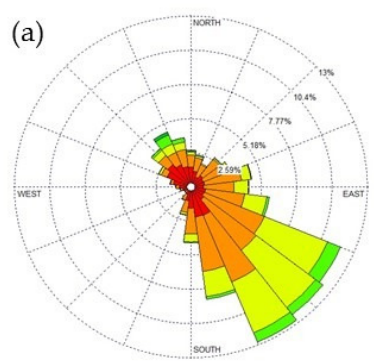

(e)

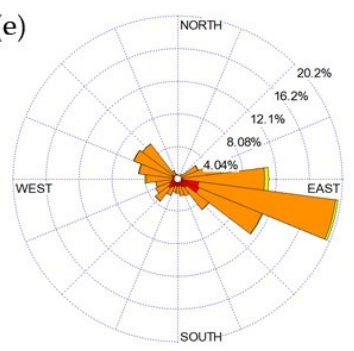

(b)

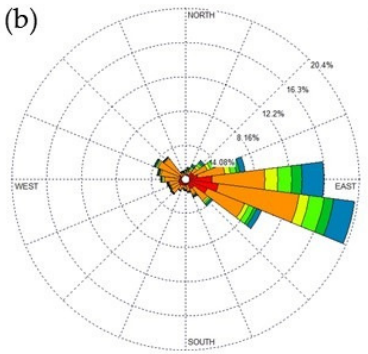

(f)

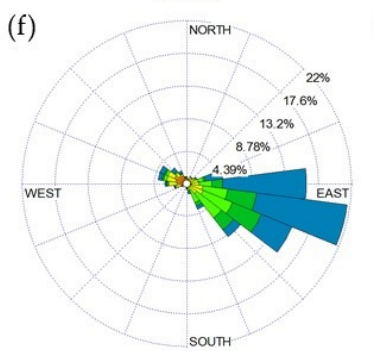

(c)

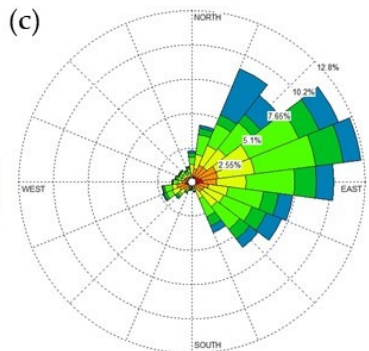

(g)

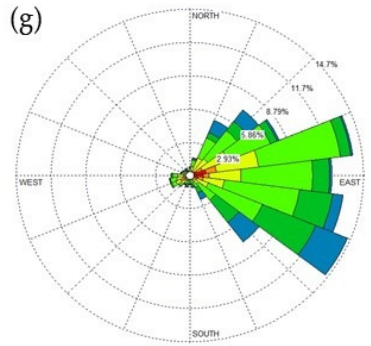

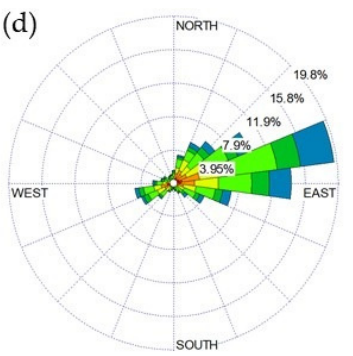

(d)

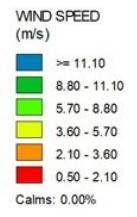

Figure 3. Wind rose plot during the experimental period (January 2019 to January 2020) for studied monitoring sites. (a) Cadereyta, (b) Escobedo, (c) Obispado (d) Pastora, (e) Pueblo Serena, (f) Santa Catarina, and (g) Universidad.

The concentration of suspended particles less than $10 \mu \mathrm{m}\left(\mathrm{PM}_{10}\right)$ showed an annual average for all sites of $53.66 \pm 0.38 \mu \mathrm{g} \mathrm{m}^{-3}$, with a minimum of $2 \mu \mathrm{g} \mathrm{m}^{-3}$ and a maximum of $600 \mu \mathrm{g} \mathrm{m}^{-3}$. The site with the highest average $\mathrm{PM}_{10}$ concentration $\left(62.16 \mathrm{\mu g} \mathrm{m}^{-3}\right)$ was Santa Catarina and the one that showed the lowest concentration $\left(44.94 \mu^{g^{-3}}{ }^{-3}\right)$ was Pueblo Serena.

Likewise, for the concentration of suspended particles less than $2.5 \mu \mathrm{m}\left(\mathrm{PM}_{2.5}\right)$, the average of all sites was $20.88 \pm 0.17 \mu \mathrm{g} \mathrm{m}^{-3}$, with a minimum value of $1 \mu \mathrm{g} \mathrm{m}^{-3}$ and a maximum of $175 \mu \mathrm{g} \mathrm{m}^{-3}$. The site with the highest average concentration of $\mathrm{PM}_{2.5}$ was Obispado $\left(25.45 \mu \mathrm{g} \mathrm{m}^{-3}\right)$ and Pueblo Serena registered the lowest concentration $\left(15.33 \mu \mathrm{g} \mathrm{m}^{-3}\right)$.

Figure 4 shows pollution roses for two sites (Obispado and Pueblo Serena). Obispado site showed that during strong winds (about $50 \mathrm{~m} \mathrm{~s}^{-1}$ ) the concentrations of $\mathrm{PM}_{2.5}$ observed were the lowest, and the winds come from Northeast. Meanwhile, the higher concentrations observed in Obispado site were prevalent during low-speed winds $\left(10 \mathrm{~m} \mathrm{~s}^{-1}\right)$, which indicate that local emission was the main source that caused elevated concentrations episodes of $\mathrm{PM}_{2.5}$. In contrast, Pueblo Serena site shows that when $\mathrm{PM}_{2.5}$ concentrations are low the winds come from the Southwest (Sierra Madre Oriental Mountain range). Although the highest concentrations come from the Northwest (MAM), 
the wind is really low (breeze) for this site throughout the year, given that the site is in the middle of two large orographic barriers (Sierra Madre Oriental Mountain range and the Cerro de la Silla), which indicates that the high concentrations did not arrive at Pueblo Serena by the wind's drag, but were being generated locally, due to the proximity of the $\mathrm{PM}_{2.5}$ sensor with National Highway 85 .
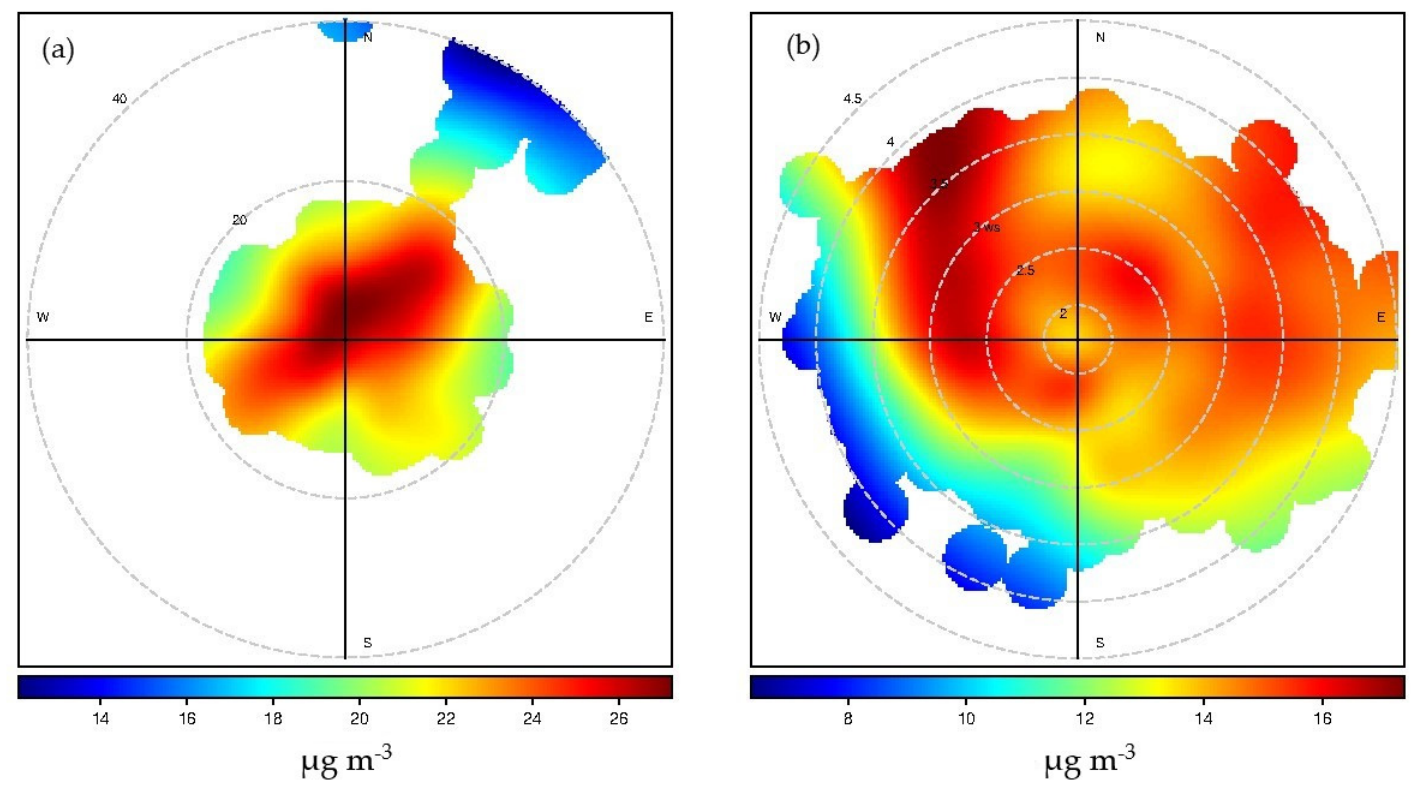

Figure 4. Pollution roses for (a) Obispado and (b) Pueblo Serena site.

The air mass backward trajectories make it possible to identify the contributions of long-distance emissions and separate their effects from local emissions. Figure 5 shows the air mass backward trajectories in order to identify where the air masses came from before occurrence of the rain events and how the air masses moved on during, using 24-h return trajectories, at a height of $500 \mathrm{~m}$ above ground level. The air mass for the Obispado site on 5 March 2019 came from the North of the country (blue line) one day before the rainfall event, which even coincides with the cold fronts season for this zone. In addition, air mass from central Mexico (red line) was observed on the rainfall event day. The air mass during 11 July 2019 came from the East of the country, from the state of Tamaulipas both trajectories, one day before and the day of the rainfall event. These trajectories can be influenced by the prevailed conditions on the Gulf of Mexico. 


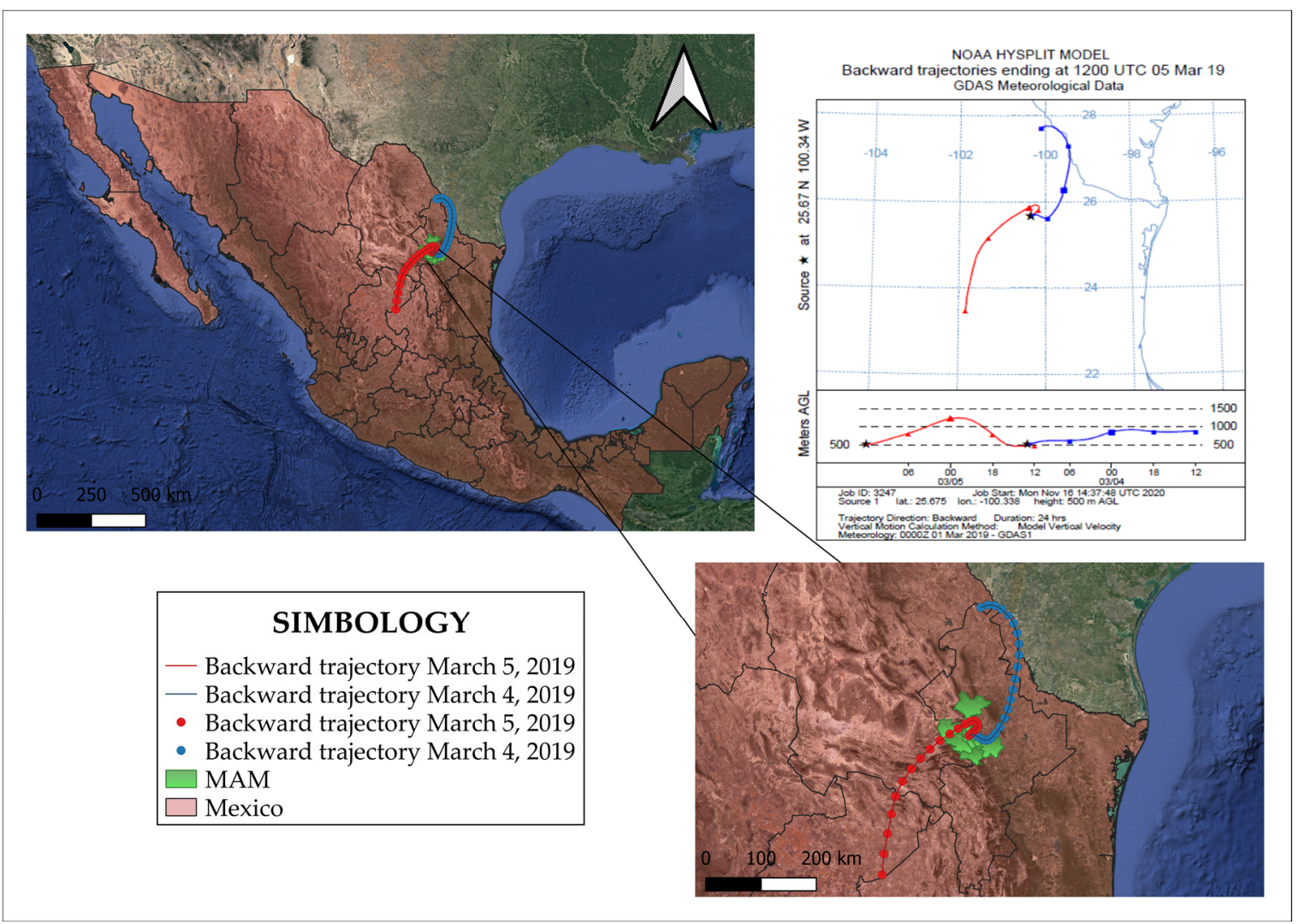

(a)

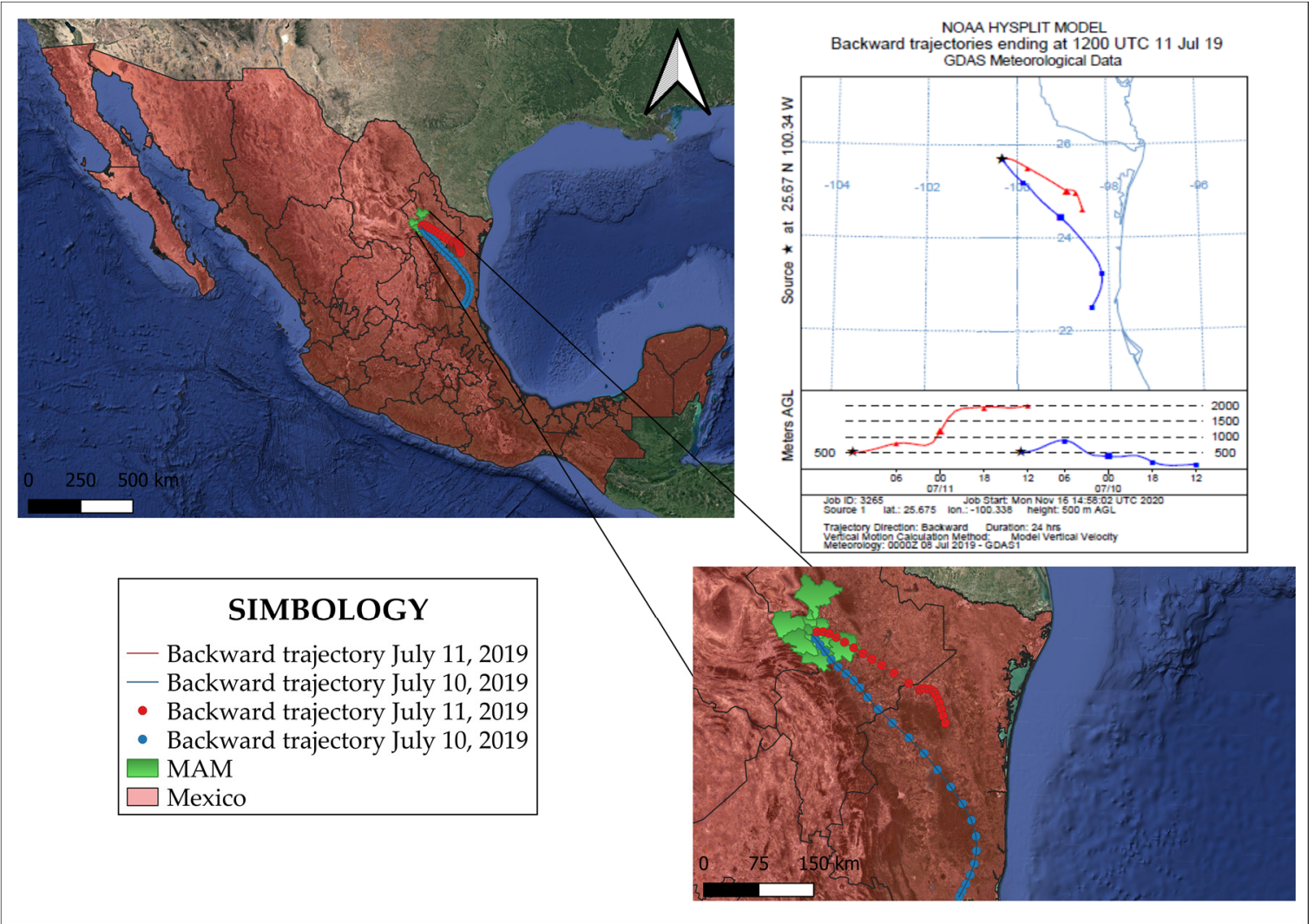

(b)

Figure 5. Air mass backward trajectories for the MAM (a) 5 March 2019 and (b) 11 July 2019. 


\subsection{Chemical Composition and Seasonal Variation}

The descriptive statistical values per monitoring site for $\mathrm{pH}, \mathrm{EC}$, precipitation, and concentration of the studied metals are shown in Table 1.

Table 1. Descriptive statistics for $\mathrm{pH}, \mathrm{EC}\left(\mu \mathrm{S} \mathrm{cm}{ }^{-1}\right)$, and annual metal concentration ( $\left.\mu \mathrm{g} \mathrm{L}^{-1}\right)$ by monitoring site.

\begin{tabular}{|c|c|c|c|c|c|c|c|c|c|}
\hline \multirow{2}{*}{ Monitoring Site } & \multirow{2}{*}{$\mathrm{pH}$} & \multirow{2}{*}{ EC } & \multirow{2}{*}{ Precipitation } & $\mathrm{Zn}$ & $\mathrm{Cd}$ & $\mathrm{Fe}$ & $\mathrm{Cu}$ & $\mathbf{N i}$ & Mn \\
\hline & & & & \multicolumn{6}{|c|}{$\mathrm{LOQ}=10 *, \mathrm{LOD}=5 *$} \\
\hline \multicolumn{10}{|l|}{ Cadereyta $(N=32)$} \\
\hline Mean & 7.2 & 138.2 & 35.4 & 199.4 & 10.2 & 224.3 & 12.8 & 10.5 & 10.8 \\
\hline Standard error & 0.1 & 14.6 & 20 & 14.5 & 0.1 & 56 & 1.3 & 0.3 & 0.4 \\
\hline Standard deviation & 0.6 & 82.9 & 69.3 & 81.8 & 0.6 & 316.8 & 7.2 & 1.6 & 2.1 \\
\hline Minimum value & 6.4 & 20 & 3.2 & 80 & 10 & 19 & 9 & 9 & 10 \\
\hline Maximum value & 8.4 & 410 & 252.2 & 415.4 & 11.9 & 1318 & 45 & 16 & 17 \\
\hline \multicolumn{10}{|l|}{ Escobedo $(N=36)$} \\
\hline Mean & 7.1 & 154.2 & 25.6 & 173.7 & 10.2 & 109.8 & 12.1 & 10 & 11 \\
\hline Standard error & 0.1 & 16.4 & 16.3 & 16.7 & 0.1 & 19.7 & 0.7 & 0 & 0.6 \\
\hline Standard deviation & 0.7 & 98.6 & 63 & 100.1 & 0.6 & 118.4 & 4.2 & 0 & 3.6 \\
\hline Minimum value & 6.2 & 10 & 2.7 & 25.7 & 10 & 10 & 10 & 10 & 10 \\
\hline Maximum value & 8.6 & 391 & 252.2 & 440 & 11.9 & 400 & 24 & 10 & 31.3 \\
\hline \multicolumn{10}{|l|}{ Obispado $(N=50)$} \\
\hline Mean & 7.2 & 182.2 & 22.1 & 263.4 & 12.6 & 443.7 & 25.7 & 10.7 & 21.3 \\
\hline Standard error & 0.1 & 22.8 & 2.5 & 23.4 & 1.4 & 126 & 6.8 & 0.4 & 3.6 \\
\hline Standard deviation & 0.5 & 161 & 45.4 & 165.7 & 9.8 & 891 & 48.1 & 2.8 & 25.7 \\
\hline Minimum value & 6.5 & 20 & 1.3 & 12.4 & 10 & 10 & 10 & 9 & 10 \\
\hline Maximum value & 9.2 & 744 & 201.8 & 644 & 51 & 4396 & 214 & 21.5 & 127 \\
\hline \multicolumn{10}{|l|}{ Pastora $(N=52)$} \\
\hline Mean & 7.1 & 206.9 & 23 & 210.1 & 10.3 & 299.6 & 14.9 & 10 & 20.3 \\
\hline Standard error & 0.1 & 26.2 & 1.8 & 15 & 0.1 & 76.8 & 1.1 & 0 & 3.6 \\
\hline Standard deviation & 0.5 & 188.9 & 36.8 & 108.5 & 0.8 & 553.5 & 7.8 & 0.3 & 26 \\
\hline Minimum value & 5.9 & 10 & 1.8 & 15.8 & 10 & 10 & 10 & 10 & 10 \\
\hline Maximum value & 8.7 & 814 & 161.4 & 452 & 13.6 & 3337 & 34 & 12 & 155 \\
\hline \multicolumn{10}{|l|}{ Pueblo Serena $(N=52)$} \\
\hline Mean & 7.1 & 104.9 & 28 & 204.5 & 14 & 277.3 & 10.8 & 10 & 16.9 \\
\hline Standard error & 0.1 & 10.3 & 3 & 12.6 & 2.1 & 67.8 & 0.5 & 0 & 2.6 \\
\hline Standard deviation & 0.4 & 74 & 56.2 & 91 & 15.2 & 488.6 & 3.5 & 0 & 18.6 \\
\hline Minimum value & 6.4 & 10 & 1.9 & 15.3 & 10 & 9.5 & 9 & 10 & 10 \\
\hline Maximum value & 8.3 & 350 & 252.2 & 402 & 74.6 & 2949 & 31 & 10 & 103 \\
\hline \multicolumn{10}{|l|}{ Santa Catarina $(N=42)$} \\
\hline Mean & 7.3 & 222.1 & 24.1 & 241.1 & 10.2 & 465.4 & 15 & 21.9 & 22.9 \\
\hline Standard error & 0.1 & 24 & 14.4 & 24.1 & 0.1 & 146.8 & 1.3 & 8.3 & 5.5 \\
\hline Standard deviation & 0.7 & 155.6 & 59.5 & 156.2 & 0.6 & 951.6 & 8.6 & 53.8 & 35.6 \\
\hline Minimum value & 6.2 & 10 & 1.3 & 12.4 & 10 & 10 & 10 & 10 & 10 \\
\hline Maximum value & 9.3 & 701 & 252.2 & 669 & 11.9 & 3712 & 37 & 26 & 149 \\
\hline \multicolumn{10}{|l|}{ Universidad $(N=37)$} \\
\hline Mean & 7.2 & 240.8 & 28.1 & 405.3 & 10.1 & 1090.8 & 28.4 & 10.7 & 35.6 \\
\hline Standard error & 0.1 & 30.8 & 13.6 & 46 & 0.1 & 358 & 9.3 & 0.5 & 12 \\
\hline Standard deviation & 0.5 & 187.2 & 57.9 & 280.1 & 0.5 & 2177.5 & 56.4 & 3.3 & 72.7 \\
\hline Minimum value & 6.4 & 10 & 1.3 & 110.4 & 9.7 & 20 & 10 & 10 & 10 \\
\hline Maximum value & 8.2 & 720 & 252.2 & 1492 & 11.9 & 9329 & 345 & 30 & 424 \\
\hline
\end{tabular}

* Analytical method limits of quantification (LOQ) and detection (LOD).

The average $\mathrm{pH}$ value for all sampling sites was $7.2 \pm 0.3$, with a minimum value of 5.9 and a maximum of 9.3. The electrical conductivity (EC) showed an average of $177.8 \pm 8.7 \mu \mathrm{s} \mathrm{cm}{ }^{-1}$, with a minimum of $10 \mu \mathrm{S} \mathrm{cm}{ }^{-1}$ and a maximum of $814 \mu \mathrm{S} \mathrm{cm} \mathrm{cm}^{-1}$.

The concentrations of $\mathrm{Zn}$ and Fe showed the highest values in all studied sites with respect to the rest of the metals. In addition, it could be noted that the Universidad site registered the highest average 
values for these two elements, as well for $\mathrm{Cu}$ and $\mathrm{Mn}\left(\mathrm{Zn}=405.3 \pm 46 \mu \mathrm{g} \mathrm{L}^{-1}, \mathrm{Fe}=1090.8 \pm 358 \mu \mathrm{g} \mathrm{L}^{-1}\right.$, $\mathrm{Cu}=28.4 \pm 9.3 \mu \mathrm{g} \mathrm{L}^{-1}$, and $\mathrm{Mn}=35.6 \pm 12 \mu \mathrm{g} \mathrm{L}^{-1}$ ) with respect to the remaining sites. The site that showed the highest average value for the concentration of $\mathrm{Cd}\left(14 \pm 2.1 \mu \mathrm{g} \mathrm{L}^{-1}\right)$ was Pueblo Serena and the highest Ni concentration $\left(21.9 \pm 8.3 \mu \mathrm{g} \mathrm{L}{ }^{-1}\right)$ was found in Santa Catarina site.

The descending order of monitoring sites for the average concentrations of Fe was as follows: Universidad $>$ Santa Catarina $>$ Obispado $>$ Pastora $>$ Pueblo Serena $>$ Cadereyta $>$ Escobedo, and for Zn the descending order of sites was: Universidad $>$ Obispado $>$ Santa Catarina $>$ Pastora $>$ Pueblo Serena $>$ Cadereyta $>$ Escobedo.

$\mathrm{Fe}, \mathrm{Zn}, \mathrm{Cu}$, and $\mathrm{Mn}$ concentrations showed a clear seasonal variation, while $\mathrm{Ni}$ and $\mathrm{Cd}$ did not exhibit any seasonal variability. Iron and zinc concentrations were the highest and most variable along the monitoring period for all sites. Nickel and Cadmium showed the lowest concentrations, which were constant throughout the study period. Spatial and temporal distribution concentrations of metals bulk precipitation in MAM are shown in Figure 6.

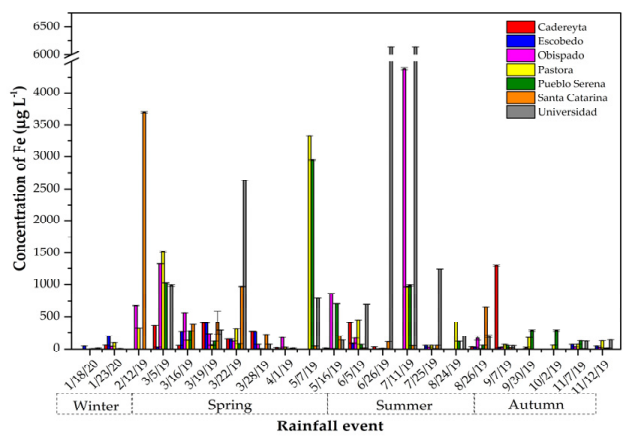

(a)

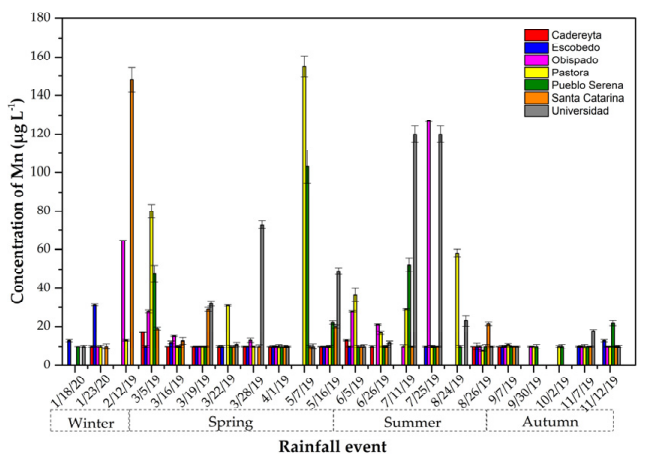

(c)

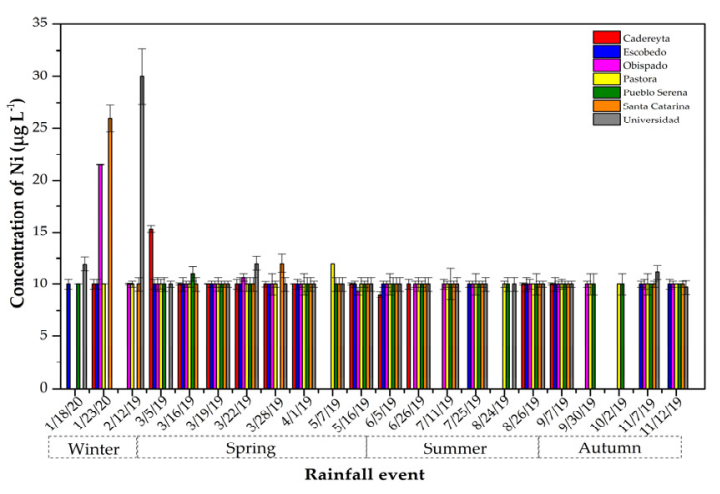

(e)

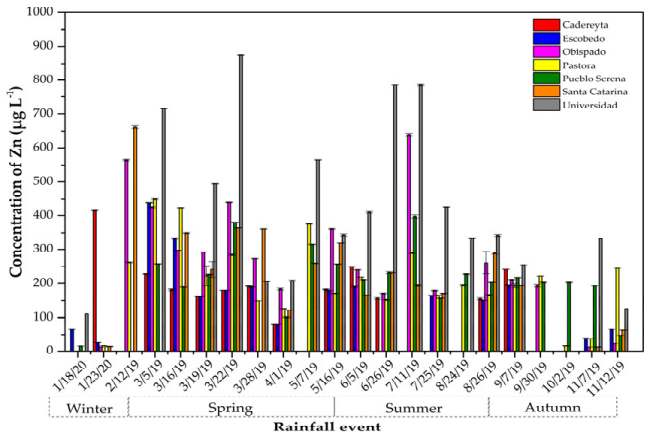

(b)

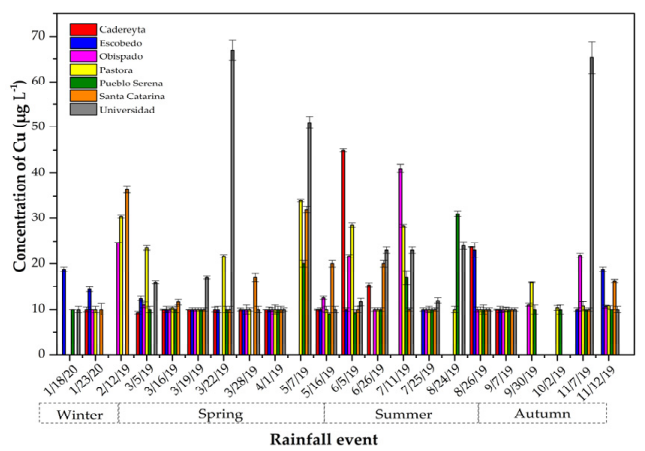

(d)

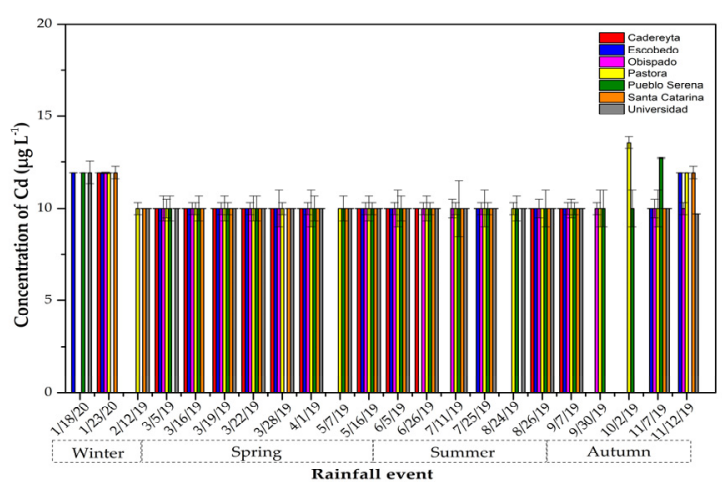

(f)

Figure 6. Spatial and temporal distribution concentrations of metals in bulk precipitation in MAM, (a) Fe, (b) Zn, (c) Mn, (d) Cu, (e) Ni and, (f) Cd. Plotted data are means \pm standard error. 
The global descending order for analyzed metals was as follows: $\mathrm{Fe}>\mathrm{Zn}>\mathrm{Mn}>\mathrm{Cu}>\mathrm{Ni}>\mathrm{Cd}$. The trend and extent of the mean values for studied metals can be observed for each monitoring site in Figure 7.

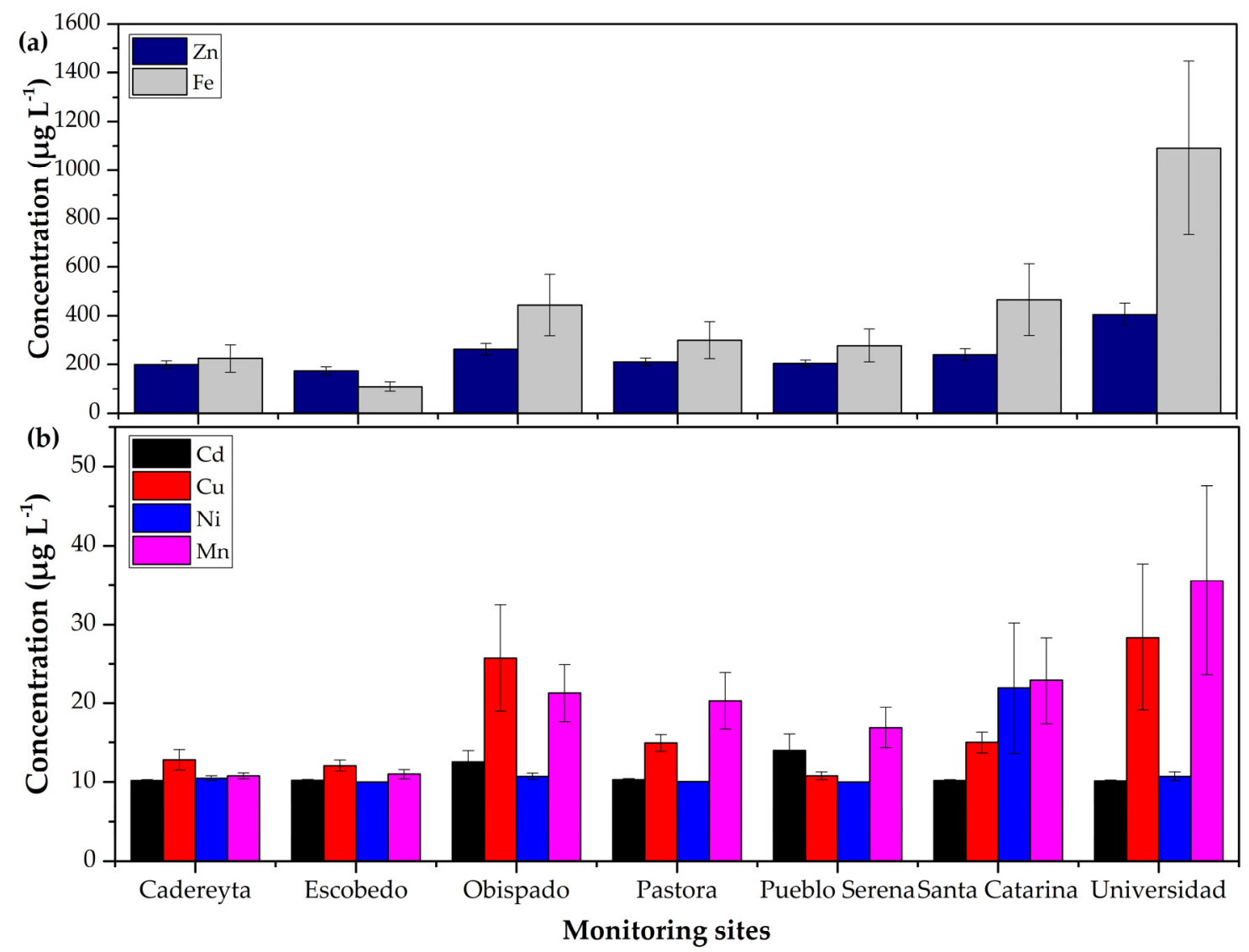

Figure 7. Average concentrations of (a) $\mathrm{Zn}$ and $\mathrm{Fe},(\mathbf{b}) \mathrm{Cd}, \mathrm{Cu}, \mathrm{Ni}$ and $\mathrm{Mn}$, for each monitoring site. Plotted data are means \pm standard error.

The Kruskal-Wallis test showed no significant differences in the mean values of the variable precipitation, $\mathrm{pH}, \mathrm{Cd}$, and $\mathrm{Ni}$ among sampling sites. In contrast, the analysis indicated significant differences for the mean values of EC, $\mathrm{Zn}, \mathrm{Fe}, \mathrm{Cu}$, and $\mathrm{Mn}$ among sampling sites (Table 2). Regarding the rainfall events, significant differences were found among sampling dates for all the parameters analyzed (precipitation, $\mathrm{pH}, \mathrm{EC}$, and studied metals).

Table 2. Statistics of the Kruskal-Wallis analysis of variance between the monitoring sites and between rainfall events.

\begin{tabular}{|c|c|c|c|c|c|c|c|c|c|}
\hline Statistic & Precipitation & $\mathrm{pH}$ & $\mathrm{CE}$ & Zn & $\mathrm{Cd}$ & $\mathbf{F e}$ & $\mathrm{Cu}$ & $\mathrm{Ni}$ & Mn \\
\hline & \multicolumn{9}{|c|}{ Grouping by monitoring sites $(\mathrm{df}=6)$} \\
\hline$x^{2}$ & 9.623 & 3.69 & 26.56 & 38.11 & 6.23 & 13.35 & 34.72 & 8.70 & 17.32 \\
\hline & \multicolumn{9}{|c|}{ Grouping by rainfall events $(\mathrm{df}=21)$} \\
\hline$x^{2}$ & 156.51 & 195.68 & 183.33 & 143.30 & 168.53 & 128.97 & 109.06 & 62.22 & 121.25 \\
\hline$p$-value & $<0.001^{* * *}$ & $<0.001^{* * *}$ & $<0.001^{* * *}$ & $<0.001^{* * *}$ & $<0.001^{* * *}$ & $<0.001 * * *$ & $<0.001 * * *$ & $<0.001 * * *$ & $<0.001^{* * *}$ \\
\hline
\end{tabular}

${ }^{*}(p \leq 0.05)$ significant differences. ${ }^{* *}(p \leq 0.01)$ significant differences. ${ }^{* * *}(p \leq 0.001)$ highly significant differences.

NS $(p>0.05)$ not significant differences.

In pollution analysis, the correlations between two heavy metals regularly indicates that these elements come from the same source when the correlation is positive, while a negative correlation shows that they come from different sources [27]. Spearman correlation test was used to evaluate the 
relationship between metals concentrations in bulk precipitation as shown in Table 3. The analysis showed significant but positive moderate correlations between $\mathrm{Zn}-\mathrm{Fe}, \mathrm{Zn}-\mathrm{Mn}$, Fe-Mn, and $\mathrm{Cu}-\mathrm{Mn}$, suggesting that these species could be emitted from a common source of origin. In addition, significant but negative low correlations were found for $\mathrm{Zn}-\mathrm{Cd}$ and $\mathrm{Cd}-\mathrm{Fe}$, and positive low exist for $\mathrm{Zn}-\mathrm{Cu}$, $\mathrm{Fe}-\mathrm{Cu}$, and $\mathrm{Cd}-\mathrm{Ni}$.

Table 3. Spearman correlations coefficients for the metal concentration in bulk precipitation (moderate to strong correlations $>0.5$ are shown in bold).

\begin{tabular}{|c|c|c|c|c|c|c|}
\hline & $\mathrm{Zn}$ & Cd & $\mathbf{F e}$ & $\mathrm{Cu}$ & $\mathrm{Ni}$ & Mn \\
\hline $\mathrm{Zn}$ & & $-0.22 * *$ & $0.691 * *$ & $0.373^{* *}$ & 0.003 & $0.582 * *$ \\
\hline Cd & & & $-0.172^{* *}$ & 0.026 & 0.141 * & 0.012 \\
\hline $\mathrm{Fe}$ & & & & $0.336^{* *}$ & -0.002 & $0.675^{* *}$ \\
\hline $\mathrm{Cu}$ & & & & & 0.051 & $0.533^{* *}$ \\
\hline $\mathrm{Ni}$ & & & & & & 0.113 \\
\hline Mn & & & & & & \\
\hline
\end{tabular}

* Correlations is significant at the 0.05 level (2 tails). The highest correlations found are shown in bold. ${ }^{* *}$ Correlations is significant at the 0.01 level ( 2 tails).

\subsection{Toxicity Potential Index (TP)}

The calculated values for toxicity potential for the MAM are shown in Table 4. TP values greater than one (TP $>1$ ) were observed only for $\mathrm{Cd}$ and $\mathrm{Fe}$, which were obtained using upper limits of drinking water from both countries (Mexico and USA), since the maximum permissible limit for these metals are consistent in both regulations. Cd showed toxicity potential risk in all monitoring sites, while TP values of Fe showed potential risk only for Universidad (TP = 3.64), Obispado (TP = 1.48), Pastora (TP $=1)$ and Santa Catarina (TP = 1.55) sites. On the other hand, $\mathrm{Zn}, \mathrm{Cu}$, and $\mathrm{Mn}$ did not represent a toxicity potential risk according to TP values obtained which were smaller than one (TP $<1)$.

Table 4. Toxicity potential (TP) values of studied metals evaluated under two different upper limits (EPA-Environmental Protection Agency and NOM-Mexican regulations) by monitoring sites.

\begin{tabular}{lccccccccccc}
\hline \multirow{2}{*}{ Site } & \multicolumn{2}{c}{ Cd } & \multicolumn{2}{c}{ Fe } & \multicolumn{2}{c}{ Zn } & \multicolumn{2}{c}{ Cu } & \multicolumn{3}{c}{ Mn } \\
\cline { 2 - 12 } & EPA & NOM & EPA & NOM & EPA & NOM & EPA & NOM & EPA & NOM \\
\hline Cadereyta & $\mathbf{2 . 0 3 6}$ & $\mathbf{2 . 0 3 6}$ & 0.748 & 0.748 & 0.040 & 0.040 & 0.013 & 0.006 & 0.215 & 0.072 \\
Escobedo & $\mathbf{2 . 0 4 3}$ & $\mathbf{2 . 0 4 3}$ & 0.366 & 0.366 & 0.035 & 0.035 & 0.012 & 0.006 & 0.220 & 0.073 \\
Obispado & $\mathbf{2 . 5 1 5}$ & $\mathbf{2 . 5 1 5}$ & $\mathbf{1 . 4 7 9}$ & $\mathbf{1 . 4 7 9}$ & 0.053 & 0.053 & 0.026 & 0.013 & 0.425 & 0.142 \\
Pastora & $\mathbf{2 . 0 5 9}$ & $\mathbf{2 . 0 5 9}$ & $\mathbf{0 . 9 9 9}$ & $\mathbf{0 . 9 9 9}$ & 0.042 & 0.042 & 0.015 & 0.007 & 0.406 & 0.135 \\
Pueblo Serena & $\mathbf{2 . 7 9 9}$ & $\mathbf{2 . 7 9 9}$ & 0.924 & 0.924 & 0.041 & 0.041 & 0.011 & 0.005 & 0.338 & 0.113 \\
Santa Catarina & $\mathbf{2 . 0 3 7}$ & $\mathbf{2 . 0 3 7}$ & $\mathbf{1 . 5 5 1}$ & $\mathbf{1 . 5 5 1}$ & 0.048 & 0.048 & 0.015 & 0.007 & 0.457 & 0.152 \\
Universidad & $\mathbf{2 . 0 2 7}$ & $\mathbf{2 . 0 2 7}$ & $\mathbf{3 . 6 3 6}$ & $\mathbf{3 . 6 3 6}$ & 0.081 & 0.081 & 0.028 & 0.014 & 0.711 & 0.237 \\
\hline
\end{tabular}

\subsection{Canonical Correlation Analysis (CCA)}

The canonical correlation analysis (CCA) was used to determine the relationships between two sets of variables: deposition of metals ( $\mathrm{Fe}, \mathrm{Zn}, \mathrm{Mn}, \mathrm{Cu}, \mathrm{Ni}$, and $\mathrm{Cd}, \mathrm{mg} \mathrm{m}^{-2}$ ) and the environmental variables (relative humidity, wind direction and speed, and particulate matter). The linear combinations of each set were maximized in such a way that the correlation between both sets was as high as possible. The CCA shows how the presence of metals in rainwater can be explained by environmental variables. Figure 8 shows the diagram obtained from the canonical correlations between the two groups, which includes the data from all monitoring sites and all the analyzed events. 


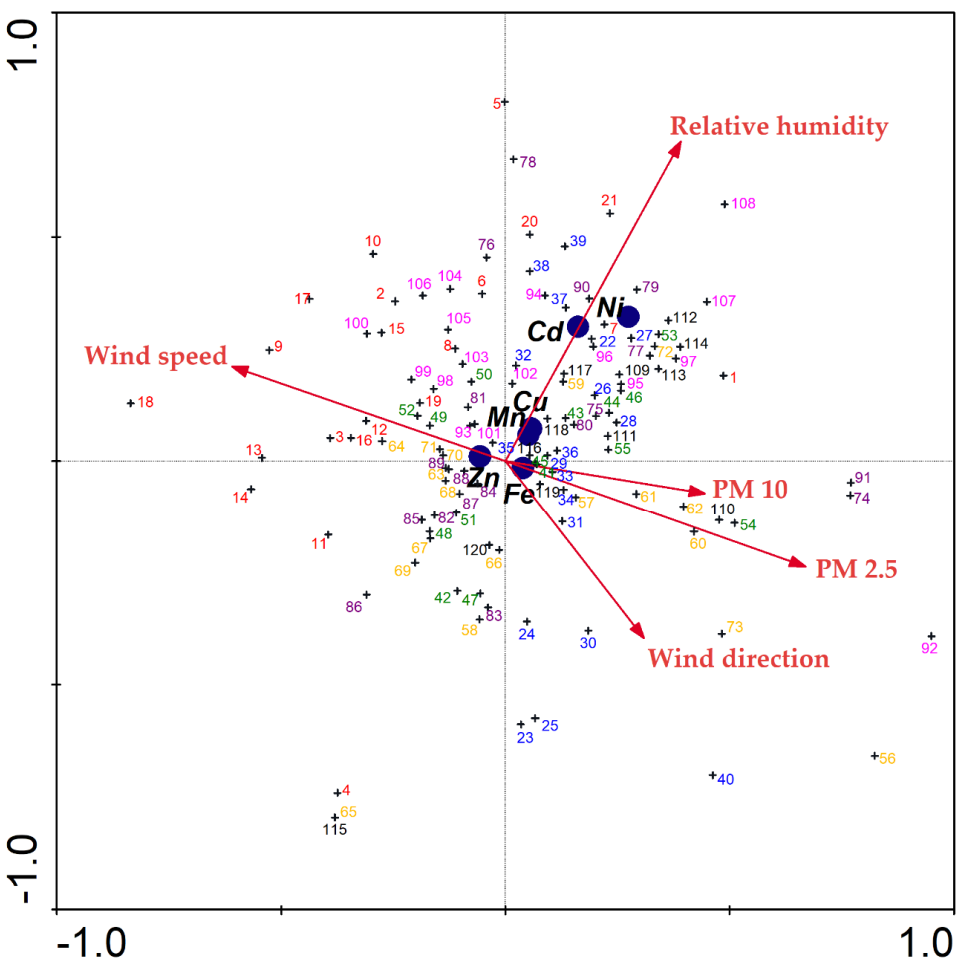

Figure 8. Graphical representation of the CCA between metal concentrations (in bold) and environmental variables (red arrow) for all studied sites. Numbers with different colors represent the events for each site, red (Pastora), green (Escobedo), yellow (Obispado), blue (Pueblo Serena), purple (Universidad), magenta (Santa Catarina) and black (Cadereyta).

CCA analysis for the entire data set shows that the highest correlations were found between $\mathrm{Ni}$ and $\mathrm{Cd}$ with relative humidity, $\mathrm{Fe}$ is associated with particles, although its relationship was low because it was found very close to the plot origin. With respect to $\mathrm{Zn}$, it seems to be more closely related to wind speed, although the relationship was also low. Finally, $\mathrm{Mn}$ and $\mathrm{Cu}$ were also more related to relative humidity, although this relationship was lower than that shown by $\mathrm{Cd}$ and $\mathrm{Ni}$. The values of the axes and the canonical correlations are also illustrated in Table 5. Axis 1 (horizontal), which explains the phenomenon in a higher percentage, shows a correlation between the metals analyzed and the environmental variables of 0.398 , and this axis explains $62 \%$ of the variability of the phenomenon. The next most relevant axis is axis 2 (vertical), which shows a correlation of 0.248 . Both axes explain a total of $86 \%$ of the variability of the phenomenon. The correlation between metals and environmental variables is relatively low, despite reaching $86 \%$ of the variation of the phenomenon. This happens due to the fact that only two metals (Ni and $\mathrm{Cd}$ ) are correlated with an environmental variable (relative humidity) of the entire set of metals analyzed (6) and the environmental variables (5), therefore, the global correlations of the axes are low.

Table 5. Axis values of global canonical correlation analysis.

\begin{tabular}{lccccc}
\hline \multicolumn{1}{c}{ Axes } & $\mathbf{1}$ & $\mathbf{2}$ & $\mathbf{3}$ & $\mathbf{4}$ & Total Inertia \\
\hline Eigenvalues & 0.061 & 0.024 & 0.012 & 0.002 & 1.163 \\
Metals-environment correlations & 0.398 & 0.248 & 0.184 & 0.249 & \\
Cumulative percentage of variance & & & & & \\
Of metals data & 5.2 & 7.2 & 8.2 & 8.4 & \\
Of metals-environment relation & 62.2 & 86.4 & 98.3 & 100 & \\
Sum of all eigenvalues & & & & & 0.163 \\
Sum of all canonical eigenvalues & & & & & 0.098 \\
\hline
\end{tabular}




\section{Discussion}

\subsection{Environmental Variables}

The rainfall events showed the highest precipitation amount during March, September, and October. The accumulated monthly precipitation was higher in September, due to the influence of tropical storm Fernand. Despite the fact that the MAM or the state of Nuevo Leon are not close to the coastline, torrential rains are common due to tropical storms that enter via the Gulf of Mexico, mainly during the months of August and September, as occurs within the reported sampling year.

The backward trajectories calculated for the MAM show that the predominant air mass influence during the summer comes from the Gulf of Mexico, and from the Northeast during the winter, where the cold air masses have great influence on the local atmospheric dynamic. However, given the elements analyzed and the previously described particle characteristics of the MAM, it can be understood that the influence of long-distance sources of emission have little relevance when compared to local emission sources, at least for the metals investigated in this study. The MAM is a potential source of emissions when compared to regional emission sources, from where prevailing air masses arrive. Thus, the MAM should be analyzed according to the forward trajectories to know their possible effects on other areas.

In the case of the Obispado site, according to the respective pollution rose, the highest concentration of suspended particulate matter is generated locally, due to the high vehicular load of this site. Study of the composition of $\mathrm{PM}_{2.5}$ at this monitoring site showed a high percentage of total carbon content $(44 \%)$, as well as a high Fe content (1242.30 $\left.\mathrm{ng} \mathrm{m}^{-3}\right), \mathrm{Cu}\left(603.33 \mathrm{ng} \mathrm{m}^{-3}\right), \mathrm{Zn}\left(226.76 \mathrm{ng} \mathrm{m}^{-3}\right)$, and $\mathrm{Pb}\left(35.75 \mathrm{ng} \mathrm{m}^{-3}\right)$. Likewise, Santa Catarina site showed a high concentration of $\mathrm{PM}_{10}$ for our period of study. The reported study about composition of this particulate matter also indicated high concentrations of total carbon content (49\%), as well as a high Fe content (1643.26 $\mathrm{ng} \mathrm{m}^{-3}$ ), $\mathrm{Cu}\left(1416.89 \mathrm{ng} \mathrm{m}^{-3}\right)$, Zn (189 $\left.\mathrm{ng} \mathrm{m}^{-3}\right)$, and $\mathrm{Pb}\left(57.54 \mathrm{ng} \mathrm{m}^{-3}\right)$ [17]. In contrast, Pueblo Serena site shows the lowest concentrations of suspended particulate matter $\left(\mathrm{PM}_{2.5}\right.$ and $\left.\mathrm{PM}_{10}\right)$ for this study; no information about particulate matter composition is reported.

\subsection{Chemical Composition and Seasonal Variation}

Rain samples collected during the study period showed a $\mathrm{pH}(7.2 \pm 0.3)$ above the natural background value for rain $\mathrm{pH}$ of 5.6, in all monitoring sites [28]. This tendency towards alkalinity is consistent within the MAM due to the dominance of calcareous soil (Calcisol), which influences atmospheric dynamics neutralizing the $\mathrm{pH}$ of the rain [20]. The electrical conductivity varied from 10 to $814 \mu \mathrm{S} \mathrm{cm}^{-1}$. This high variation could be explained due to the natural changing conditions with respect to seasonality and the pollution dynamics in the MAM, which can become highly variable among sites and rain events.

The concentrations of Fe and Zn showed the highest values for all the sites as already mentioned, where the Universidad site acquired the highest values for these metals, as well as for $\mathrm{Cu}$ and $\mathrm{Mn}$. The high concentrations for these elements in the site could be related to its proximity to emission sources of the metallurgical industry. Important concentration values in rainwater for Fe and $\mathrm{Zn}$ have been associated with this monitoring site [29]. In addition, a previous study of particulate matter in the Universidad site showed that Fe suspended particles came from natural and anthropogenic sources due to their morphology type characteristics since its spherical shape is associated with natural emissions while particles of more irregular shape-type to anthropogenic sources [25].

The Spearman correlation showed moderate positive relationships between $\mathrm{Zn}-\mathrm{Fe}, \mathrm{Zn}-\mathrm{Mn}, \mathrm{Fe}-\mathrm{Mn}$, and $\mathrm{Cu}-\mathrm{Mn}$. The correlation between these elements suggests that they have a common source, which could be of natural origin (soil resuspension) or anthropogenic, mainly metallurgical industry or vehicular emissions $[27,30,31]$.

The element concentrations observed in this study are higher than those reported for the Metropolitan Area of Mexico City (MAMC) for all the analyzed metals, where the average documented 
values for MAMC were: $\mathrm{Fe}=77.3, \mathrm{Cd}=0.8, \mathrm{Mn}=14.3$ and $\mathrm{Ni}=3.2 \mu \mathrm{g} \mathrm{L}{ }^{-1}$ [32]. In addition, comparing results of the present study with a research carried out for several cities in south-central Mexico, the Fe values observed in this study for the Universidad site $\left(1090.8 \mu \mathrm{g} \mathrm{L}^{-1}\right)$ exceed the values of all the cities monitored in the central-southern Mexico study ( 292 at $448 \mu \mathrm{g} \mathrm{L}^{-1}$ ). Likewise, the Cd concentration reported for cities in central-southern Mexico $\left(1\right.$ to $\left.4 \mu \mathrm{g} \mathrm{L}^{-1}\right)$ were lower than the values reported in the present study (10 to $13 \mu \mathrm{g} \mathrm{L}^{-1}$ ), as well as the concentrations values of $\mathrm{Cu}$ and $\mathrm{Mn}$ [8]. This means that the MAM in general shows higher concentrations of Fe and $\mathrm{Cd}$ in rainwater compared to other Mexican cities that also have a high population load and industrialization. Moreover, the MAM is above all the values reported by García-Martínez (2007) for the metropolitan area of Mexico City, which is the largest urban center in the country, the most-populous city in North America, and one of the most populated urban cities in the world.

Studies carried out in Gadanki, India, a tropical rural area near cities such as Bengaluru and Chennai showed average $\mathrm{Cd}$ values $\left(50 \mathrm{\mu g} \mathrm{L}^{-1}\right)$ five times higher than those reported by this study, and average values for $\mathrm{Ni}\left(600\right.$ to $\left.1200 \mu \mathrm{g} \mathrm{L}^{-1}\right)$ and $\mathrm{Mn}\left(30\right.$ to $\left.100 \mu \mathrm{g} \mathrm{L}^{-1}\right)$ that exceed the concentrations analyzed for the metals within the MAM. However, regarding the Zn values, Gadanki reports mean values of 50 to $80 \mu \mathrm{g} \mathrm{L}^{-1}$ which are lower than those found for the MAM (199 to $405 \mu \mathrm{g} \mathrm{L}^{-1}$ ) [27]. On the other hand, studies carried out in Yatta, Palestine, in an arid area where rainwater is important for human consumption and agriculture, for which it was considered that the load of heavy metals could directly affect human health, showed values for Fe of $137.6 \mu \mathrm{g} \mathrm{L}^{-1}$, which are below those reported for the MAM, where values of up to $1090.8 \mu \mathrm{g} \mathrm{L}^{-1}$ were reached. Despite the low values found in Yatta for $\mathrm{Fe}$, they reported that those Fe values exceeded the limit of the carcinogenic risk index. Hence placing local residents, especially children, at risk [28].

In this study, Cd was the least abundant element in the rainwater samples and Pueblo Serena site (urban/high traffic site) showed the highest average value, although Kruskal-Wallis analysis does not report significant differences between sites. Cd had been previously reported in soil samples collected from streets in downtown and south of the MAM, attributing its presence not only to vehicular traffic but also to industrial activity $[18,33]$. For $\mathrm{Ni}$, the site with the highest mean value was Santa Catarina, where this metal was associated with emissions from a power plant and the burning of fossil fuels [17]. However, the Kruskal-Wallis analysis showed that there were no significant differences for the values of $\mathrm{Cd}$ and $\mathrm{Ni}$ among sampling sites. This could be because these elements are associated to common emission sources along the entire urban basin of the MAM, as could be the emissions derived from vehicular traffic, which maintain a high flow load all over the urban area throughout the year.

\subsection{Toxicity Potential Index (TP)}

The 2019 European report on air quality articulates the concerns of the countries of the European Union regarding the environmental threat posed by air pollution to ecosystems and to human health.

Despite environmental regulations, the entry of toxic metals through rain remains a relevant issue, especially due to the bioaccumulation capacity that these elements represent when they are incorporated into the environment [34]. The metals such as $\mathrm{Cr}, \mathrm{As}, \mathrm{Cd}$, and $\mathrm{Pb}$ stand out for their high toxicity at relatively low concentrations. For this reason, their bioavailability in the environment represents a high risk to the health of wildlife and people. Furthermore, other metals that are considered less harmful such as $\mathrm{Fe}, \mathrm{Zn}$, and $\mathrm{Cu}$ may cause adverse health effects at moderate concentrations [31].

As already mentioned above, Fe showed the highest concentrations and the highest TP value (3.64) for the Universidad site; these values are related to the nearby metallurgical industry and represent a potential risk to the University community and the neighborhood.

The values obtained for TP $>1$ apply for $\mathrm{Cd}$, which show a potential risk of toxicity due to the deposition of this element by rain along the MAM. Keresztesi et al. (2020) established cadmium TP values for the city of Baile Herculane, Romania, of 14.33 and for the Moldova Noua city of 7.49, which are well above those reported by this study. 
The cadmium content of soil was studied in 2011 and 2015 in the MAM, reporting average values of $7.5 \mathrm{mg} \mathrm{kg}^{-1}$ dry soil and $0.38 \mathrm{mg} \mathrm{kg}^{-1}$ dry soil, respectively. In addition, the 2015 analysis determined that the most affected zones are south and northeast of the MAM and that according to the geoaccumulation indices, the $\mathrm{Cd}$ showed risk values between moderate and considerable. These levels were related to the influence of industrial activity, mechanical workshops, and gas stations [18,33]. However, in the present study, the site that showed the highest cadmium TP values was Pueblo Serena, which is a residential and commercial site, where its residents recognize that the air is less polluted than the rest of the MAM, since low levels of the criteria air pollutants $\left(\mathrm{PM}_{10}\right.$ and $\left.\mathrm{PM}_{2.5}\right)$, according to the applicable regulations (NOM-172-SEMARNAT-2019), have been regularly observed. Over the past few years, that area of the MAM has experienced a "boom" in housing expansion, and it should be noted that the National Highway 85 may also influence the atmospheric conditions of this site. This could explain the high levels of $\mathrm{Cd}$ in Pueblo Serena, since its residential and commercial growth has led to a dramatic increase in traffic, and it is known that $\mathrm{Cd}$ has been associated with the burning of fossil fuels by vehicles [35]. It is important to highlight that more studies are required to evaluate the presence of cadmium and more specifically its potential for toxicity in water bodies and cropping soils in the region.

Mexican regulations are commonly less strict than regulations in other countries like the USA and European countries. In some cases, the implementation and enforcement of the regulations is scarce. In addition, the control of metal deposition that can affect crops, water bodies, and ecosystems lacks any type of regulation or surveillance by the government agencies. The Metropolitan Area of Mexico City is the only one that has a constant and standardized deposition monitoring system (dry and wet) [36]. This monitoring system has not been implemented in other Mexican cities, like in highly contaminated ones such as the MAM.

\subsection{Canonical Correlation Analysis (CCA)}

The CCA analysis performed with the environmental variables and metal mass deposition $\left(\mathrm{mg} \mathrm{m}^{-2}\right)$ for all sites has shown a strong correlation linking to $\mathrm{Cd}$ and $\mathrm{Ni}$ with relative humidity. Although it was expected, given the nature of the analyzed phenomenon and because of the global deposition (wet and dry), that the deposition of metals would be influenced by particulate material and wind, the higher correlations were found with relative humidity, while lower correlations were found with wind or particulate matter. This could indicate that depositions of Cd and Ni were not related to particulate matter but associated with mist or cloud precursor phenomena, because of their correlation with relative humidity. This trend could be explained by studies that showed that there are metals that tend to have higher wet deposition fluxes than others, given their nature of solubility, where the dilution potential is considered to be as follows: $\mathrm{Zn}>\mathrm{Cd}>\mathrm{Cu}>\mathrm{Ni}>\mathrm{Pb}>\mathrm{Cr}[35,37]$. Therefore, it could be stated that relative humidity and solubility are acting together to promote the deposition of $\mathrm{Ni}$ and $\mathrm{Cd}$ within the MAM in a greater proportion than the rest of the environmental variables that could influence the presence of these metals in rainwater.

For Pueblo Serena (urban/high traffic site), the highest values of TP, the tendency of relations between environmental variables and metals was similar to the global CCA (for all sites), and the results of one year of analysis have shown that the concentrations of particulate matter were the lowest inside the MAM. This statement confirms the idea that $\mathrm{Cd}$ and Ni could be deposited because they may have evolved from a local source and then interacted with cloud precursor phenomena. However, a more extensive research is required inside the MAM and Pueblo Serena to determine the most precise sources of $\mathrm{Cd}$ emissions to the atmosphere.

Limitations of the study: the concentrations of $\mathrm{Pb}$ and $\mathrm{Cr}$ were not included in this study, because their concentrations in the rainwater samples were below the $\mathrm{LOD}\left(5\right.$ for $\mathrm{Pb}$ and 5 for $\mathrm{Cr} ; \mu \mathrm{g} \mathrm{L}{ }^{-1}$ ) of the method used. The TP values for Ni were not calculated because there was no reference value for $\mathrm{Ni}$ by the regulations for water for human consumption used. 


\section{Conclusions}

The metals concentrations found in bulk precipitation in the MAM could represent a potential risk to population, due to TP calculated values for $\mathrm{Cd}$ and Fe showing values greater than one. The difference is that $\mathrm{Cd}$ represents a risk throughout the entire MAM while Fe only represents a risk for certain sites (Universidad, Obispado, Pastora y Santa Catarina) according to Mexican and USA regulations. In addition, Pueblo Serena Site showed a higher value of TP for Cd (2.799) and Universidad for Fe (6.636). The mean values found for concentrations in all the sampling sites followed a descending order of $\mathrm{Fe}>\mathrm{Zn}>\mathrm{Mn}>\mathrm{Cu}>\mathrm{Ni}>\mathrm{Cd}$. While Fe, $\mathrm{Zn}, \mathrm{Cu}$, and Mn concentrations showed a clear seasonal variation, $\mathrm{Ni}$ and $\mathrm{Cd}$ did not present any seasonal variability. On the other hand, Universidad site exhibited the highest average concentrations for $\mathrm{Fe}, \mathrm{Zn}, \mathrm{Cu}$, and $\mathrm{Mn}$, with respect to other sites, which could indicate an influence from nearby emission sources, such as the metallurgical industry. Pueblo Serena site showed the highest average concentration of Cd, while at the Santa Catarina site the highest observed was Ni. However, no significant differences were found for $\mathrm{Cd}$ and $\mathrm{Ni}$ values among sampling sites. Besides, moderate positive relationships between $\mathrm{Zn}-\mathrm{Fe}, \mathrm{Zn}-\mathrm{Mn}$, Fe-Mn, and $\mathrm{Cu}-\mathrm{Mn}$ suggest that they have a common source, which could be of natural origin (soil resuspension) or anthropogenic (metallurgical industry or vehicular emissions).

The total precipitation collected through the year had an average of $448.23 \mathrm{~mm}$. The tropical storm Fernand caused an alteration to the annual average of rain and wind speed for the study period. A range of 12 to 21 rain events were collected and analyzed, in which an average $\mathrm{pH}$ of $7.2 \pm 0.3$ and a mean electrical conductivity of $177.8 \pm 8.7 \mu \mathrm{S} \mathrm{cm}^{-1}$ were found. The relationships established by the CCA analysis for metals in bulk precipitations and the environmental variables (relative humidity, wind direction and speed, and particulate matter) showed a strong correlation only for $\mathrm{Cd}$ and $\mathrm{Ni}$ with relative humidity.

The backward trajectories simulated for the MAM showed that the predominant air mass influence during the summer comes from the Gulf of Mexico and from the Northeast during the winter, where the cold air masses have great influence on the local atmospheric dynamics. However, the MAM acts mainly as an emitting site and not as a receptor site since the influence of local industrial emissions is more dominant than the influence of emissions from the surrounding areas.

Author Contributions: Conceptualization, D.L.-G. and I.C.-S.; Formal analysis, D.L.-G. and A.L.-R.; Investigation, D.L.-G. and D.L.-S.; Methodology, H.G.-R.; Resources, D.L.-S., J.M.A.-B. and A.L.-R.; Supervision, I.C.-S.; Writing-original draft, D.L.-G.; Writing—review and editing, J.M.A.-B., A.L.-R., H.G.-R. and I.C.-S. All authors have read and agreed to the published version of the manuscript.

Funding: This research received no external funding.

Acknowledgments: Darithsa Loya-González thanks the Consejo Nacional de Ciencias y Tecnología (CONACYT) for the scholarship provided (No. 660428). The authors are grateful for the support given by the Sistema Integral de Monitoreo Ambiental (SIMA) for the use of the environmental monitoring stations during the entire study period.

Conflicts of Interest: The authors declare no conflict of interest.

\section{References}

1. Keresztesi, Á.; Nita, I.A.; Birsan, M.V.; Bodor, Z.; Szép, R. The risk of cross-border pollution and the influence of regional climate on the rainwater chemistry in the Southern Carpathians, Romania. Environ. Sci. Pollut. Res. 2020, 27, 9382-9402. [CrossRef]

2. Xing, J.; Song, J.; Yuan, H.; Li, X.; Li, N.; Duan, L.; Qu, B.; Wang, Q.; Kang, X. Chemical characteristics, deposition fluxes and source apportionment of precipitation components in the Jiaozhou Bay, North China. Atmos. Res. 2017, 190, 10-20. [CrossRef]

3. Sicard, P.; Augustaitis, A.; Belyazid, S.; Calfapietra, C.; De Marco, A.; Fenn, M.; Bytnerowicz, A.; Grulke, N.; He, S.; Matyssek, R.; et al. Global topics and novel approaches in the study of air pollution, climate change and forest ecosystems. Environ. Pollut. 2016, 213, 977-987. [CrossRef] [PubMed] 
4. Bao, K.; Shen, J.; Wang, G.; Le Roux, G. Atmospheric deposition history of trace metals and metalloids for the last 200 years recorded by three peat cores in Great Hinggan Mountain, Northeast China. Atmosphere 2015, 6, 380-409. [CrossRef]

5. Szép, R.; Mateescu, E.; Nechifor, A.C.; Keresztesi, Á. Chemical characteristics and source analysis on ionic composition of rainwater collected in the Carpathians "Cold Pole," Ciuc basin, Eastern Carpathians, Romania. Environ. Sci. Pollut. Res. 2017, 24, 27288-27302. [CrossRef]

6. Deusdará, K.R.L.; Forti, M.C.; Borma, L.S.; Menezes, R.S.C.; Lima, J.R.S.; Ometto, J.P.H.B. Rainwater chemistry and bulk atmospheric deposition in a tropical semiarid ecosystem: The Brazilian Caatinga. J. Atmos. Chem. 2017, 74, 71-85. [CrossRef]

7. Rao, P.S.P.; Tiwari, S.; Matwale, J.L.; Pervez, S.; Tunved, P.; Safai, P.D.; Srivastava, A.K.; Bisht, D.S.; Singh, S.; Hopke, P.K. Sources of chemical species in rainwater during monsoon and non-monsoonal periods over two mega cities in India and dominant source region of secondary aerosols. Atmos. Environ. 2016, 146, 90-99. [CrossRef]

8. Rivera-Rivera, D.M.; Escobedo-Urías, D.C.; Jonathan, M.P.; Sujitha, S.B.; Chidambaram, S. Evidence of natural and anthropogenic impacts on rainwater trace metal geochemistry in central Mexico: A statistical approach. Water 2020, 12, 192. [CrossRef]

9. Sharma, A.; Kulshrestha, U.C. Wet deposition and long-range transport of major ions related to snow at Northwestern Himalayas (India). Aerosol Air Qual. Res. 2020, 1249-1265. [CrossRef]

10. Lai, I.-C.; Brimblecombe, P. Long Range Transport of Air Pollutants to Taiwan during the COVID-19 Lockdown in Hubei Province. Aerosol Air Qual. Res. 2020, 20. [CrossRef]

11. Bodor, Z.; Bodor, K.; Keresztesi, Á.; Szép, R. Major air pollutants seasonal variation analysis and long-range transport of PM10 in an urban environment with specific climate condition in Transylvania (Romania). Environ. Sci. Pollut. Res. 2020, 27, 38181-38199. [CrossRef] [PubMed]

12. Keresztesi, Á.; Birsan, M.V.; Nita, I.A.; Bodor, Z.; Szép, R. Assessing the neutralisation, wet deposition and source contributions of the precipitation chemistry over Europe during 2000-2017. Environ. Sci. Eur. 2019, 31, 1-15. [CrossRef]

13. Keresztesi, Á.; Nita, I.A.; Boga, R.; Birsan, M.V.; Bodor, Z.; Szép, R. Spatial and long-term analysis of rainwater chemistry over the conterminous United States. Environ. Res. 2020, 188. [CrossRef] [PubMed]

14. Pearson, C.; Howard, D.; Moore, C.; Obrist, D. Mercury and trace metal wet deposition across five stations in Alaska: Controlling factors, spatial patterns, and source regions. Atmos. Chem. Phys. 2019, 19, 6913-6929. [CrossRef]

15. Cao, X.; Tan, C.; Wu, L.; Luo, Y.; He, Q.; Liang, Y.; Peng, B.; Christie, P. Atmospheric deposition of cadmium in an urbanized region and the effect of simulated wet precipitation on the uptake performance of rice. Sci. Total Environ. 2020, 700, 134513. [CrossRef] [PubMed]

16. Gobierno del Estado de Nuevo León Economía Incluyente. Available online: https://www.nl.gob.mx/sites/ default/files/04_economia_incluyente.pdf (accessed on 9 October 2020).

17. González, L.T.; Longoria-Rodríguez, F.E.; Sánchez-Domínguez, M.; Leyva-Porras, C.; Acuña-Askar, K.; Kharissov, B.I.; Arizpe-Zapata, A.; Alfaro-Barbosa, J.M. Seasonal variation and chemical composition of particulate matter: A study by XPS, ICP-AES and sequential microanalysis using Raman with SEM/EDS. J. Environ. Sci. 2018, 74, 32-49. [CrossRef] [PubMed]

18. Valdez Cerda, E.; Hinojosa Reyes, L.; Alfaro Barbosa, J.M.; Elizondo-Martinez, P.; Acuña-Askar, K. Contamination and chemical fractionation of heavy metals in street dust from the Metropolitan Area of Monterrey, Mexico. Environ. Technol. 2011, 32:10, 1163-1172. [CrossRef]

19. Ramírez-Lara, E.; Miranda-Guardiola, R.; Gracia-Vásquez, Y.; Balderas-Rentería, I.; Bravo-Álvarez, H.; Sosa-Echeverría, R.; Sánchez-Álvarez, P.; Alarcón-Jiménez, A.; Torres, M.C.; Kahl, J. Chemical composition of rainwater in northeastern México. Atmosfera 2010, 23, 213-224.

20. Ramírez-Lara, E.; Cerón-Bretón, R.M.; Cerón-Bretón, J.G.; López-Chuken, U.; Kahl, J. Study of trace ions in wet deposition of an industrial site in Monterrey's Metropolitan Area, Mexico. Open J. Ecol. 2016, 6, 1-12. [CrossRef]

21. Bretón, R.M.C.; Bretón, J.G.C.; Kahl, J.; Lara, E.R.; Quiroz, A.V.C.; Guzmán, A.A.E.; García, M.M.; Hernández, G.G.A.; Canul, J.A.S.; Guzmán, A.R. Atmospheric N and S deposition fluxes in the Metropolitan Area of Monterrey, Mexico and its relation with criteria air pollutants and meteorological conditions. In Air Pollution; Olvera, J.D.R., Ed.; IntechOpen: Rijeka, Croatia, 2019; pp. 3-25. 
22. Gobierno del Estado de Nuevo León Pro Aire Nuevo León 2016-2025. Available online: https://www.gob. mx/cms/uploads/attachment/file/250974/ProAire_Nuevo_Leon.pdf (accessed on 9 October 2020).

23. López-Ayala, O.; González-Hernández, L.T.; Alcantar-Rosales, V.M.; Elizarragaz-de la Rosa, D.; Heras-Ramírez, M.E.; Silva-Vidaurri, L.G.; Alfaro-Barbosa, J.M.; Gaspar-Ramírez, O. Levels of polycyclic aromatic hydrocarbons associated with particulate matter in a highly urbanized and industrialized region in northeastern Mexico. Atmos. Pollut. Res. 2019, 10, 1655-1662. [CrossRef]

24. Yáñez-Díaz, M.I.; Cantú-Silva, I.; González-Rodríguez, H.; Uvalle-Sauceda, J.I. Redistribution of precipitaiton in three native brush species and a Eucalyptus plantings in northeastern Mexico. Tecnol. Cienc. Agua 2014, $5,71-84$.

25. INECC Sistema Nacional de Información de la Calidad del Aire, SINAICA. Available online: https: //sinaica.inecc.gob.mx/ (accessed on 3 November 2020).

26. DOF. NOM-127-SSA1-1994; Secretary of the Interior: Mexico City, Mexico, 1994.

27. Chen, L.; Zhou, S.; Wu, S.; Wang, C.; He, D. Concentration, fluxes, risks, and sources of heavy metals in atmospheric deposition in the Lihe River watershed, Taihu region, eastern China. Environ. Pollut. 2019, 255, 113301. [CrossRef] [PubMed]

28. Charlson, R.J.; Rodhe, H. Factors controlling the acidity of natural rainwater. Nature 1982, 295, 682-685. [CrossRef]

29. Céron, R.M.; Céron, J.G.; Aguilar, C.A.; Montalvo, C.; López, U.; Carballo, C.G.; Benítez, J.A.; Carillo, J.R. Variations in Criteria Pollutants and Deposition Fluxes of Trace Elements in Metropolitan Area of Monterrey, Mexico. In Proceedings of the 7th International Conference on Environmental ang Geological Science and Engineering, WSEAS, Salerno, Italy, 3-5 June 2014; pp. 321-328.

30. Quiterio, S.L.; Sousa da Silva, C.R.; Arbilla, G.; Escaleira, V. Metals in airborne particulate matter in the industrial district of Santa Cruz, Rio de Janeiro, in an annual period. Atmos. Environ. 2004, 38, 321-331. [CrossRef]

31. González, L.T.; Longoria Rodríguez, F.E.; Sánchez-Domínguez, M.; Cavazos, A.; Leyva-Porras, C.; Silva-Vidaurri, L.G.; Acuña Askar, K.; Kharissov, B.I.; Villarreal Chiu, J.; Alfaro Barbosa, J.M. Determination of trace metals in TSP and PM2.5 materials collected in the Metropolitan Area of Monterrey, Mexico: A characterization study by XPS, ICP-AES and SEM-EDS. Atmos. Res. 2018, 196, 8-22. [CrossRef]

32. García-Martinez, R. Determinación de Metales Pesados en la Precipitación Pluvial de una Zona Urbana (Cd. México) y una Zona Rural (Rancho viejo, Edo. de México); Universidad Nacional Autónoma de México: Mexico City, Mexico, 2007.

33. Castillo-Nava, D.; Elias-Santos, M.; López-Chuken, U.J.; Valdés-González, A.; de la Riva-Solís, L.G.; Vargas-Pérez, M.P.; Galán-Wong, L.J.; Luna-Olvera, H.A. Heavy metals (lead, cadmium and zinc) from street dust in Monterrey, Mexico: Ecological risk index. Int. J. Environ. Sci. Technol. 2020, 17, 3231-3240. [CrossRef]

34. EEA. Air Quality in Europe-2019 Report; European Environment Agency: København, Denmark, 2019. [CrossRef]

35. Siudek, P.; Frankowski, M. Atmospheric deposition of trace elements at urban and forest sites in central Poland-Insight into seasonal variability and sources. Atmos. Res. 2017, 198, 123-131. [CrossRef]

36. Gobierno de la Ciudad de México Red de Depósito Atmosférico (REDDA). Available online: http://www. aire.cdmx.gob.mx/default.php?opc=\%27aKBk\%27 (accessed on 17 November 2019).

37. Gunawardena, J.; Egodawatta, P.; Ayoko, G.A.; Goonetilleke, A. Atmospheric deposition as a source of heavy metals in urban stormwater. Atmos. Environ. 2013, 68, 235-242. [CrossRef]

Publisher's Note: MDPI stays neutral with regard to jurisdictional claims in published maps and institutional affiliations.

(C) 2020 by the authors. Licensee MDPI, Basel, Switzerland. This article is an open access article distributed under the terms and conditions of the Creative Commons Attribution (CC BY) license (http://creativecommons.org/licenses/by/4.0/). 